\title{
Banking Supervision, Monetary Policy and Risk-Taking: Big Data Evidence from 15 Credit Registers*
}

\author{
Carlo Altavilla
}

\author{
Miguel Boucinha
}

José-Luis Peydró

\author{
Frank Smets
}

\begin{abstract}
We analyse the effects of supranational versus national banking supervision on credit supply, and its interactions with monetary policy. For identification, we exploit: (i) a new, proprietary dataset based on 15 European credit registers; (ii) the institutional change leading to the centralisation of European banking supervision; (iii) high-frequency monetary policy surprises; (iv) differences across euro area countries, also vis-à-vis non-euro area countries. We show that supranational supervision reduces credit supply to firms with very high ex-ante and ex-post credit risk, while stimulating credit supply to firms without loan delinquencies. Moreover, the increased risk-sensitivity of credit supply driven by centralised supervision is stronger for banks operating in stressed countries. Exploiting heterogeneity across banks, we find that the mechanism driving the results is higher quantity and quality of human resources available to the supranational supervisor rather than changes in incentives due to the reallocation of supervisory responsibility to the new institution. Finally, there are crucial complementarities between supervision and monetary policy: centralised supervision offsets excessive bank risk-taking induced by a more accommodative monetary policy stance, but does not offset more productive risk-taking. Overall, we show that using multiple credit registers - first time in the literature - is crucial for external validity.
\end{abstract}

JEL codes: E51, E52, E58, G01, G21, G28.

Keywords: Supervision, banking, AnaCredit, monetary policy, euro area crisis.

\footnotetext{
* Altavilla is from the European Central Bank and CEPR. Boucinha is from the European Central Bank. Smets is from the European Central Bank, University of Ghent and CEPR. Peydró is from Imperial College London, ICREA-Universitat Pompeu Fabra-CREI-Barcelona GSE, and CEPR. Emails: Carlo.Altavilla@ecb.europa.eu; Miguel.Boucinha@ecb.europa.eu; jose.peydro@gmail.com; and Frank.Smets@ecb.europa.eu. We especially thank Maria Dimou and Francesca Caucci for the excellent research assistance. We would like to thank Diana Bonfim, Luisa Carpinelli, Andrea Fabiani, Kristopher Gerardi, Victoria Ivashina, Anil Kashyap, Anna Kovner, Natalya Martynova, Atif Mian, Giacomo Ponzetto, Giorgio Primiceri, Ricardo Reis, Adi Sunderam, Enrico Sette, Lars Svensson, conference participants at the 2019 NBER Monetary Economics Program Meeting, 46th EFA Annual Meeting, ECB 2018 Annual Conference on Monetary Policy, 2018 Annual Meeting of the Central Bank Research Association (CEBRA), $12^{\text {th }}$ Swiss Winter Conference on Financial Intermediation, the 6th Workshop in Macro Banking and Finance (Alghero), 27th CEPR European Summer Symposium in International Macroeconomics (Spain), IAAE 2019 Annual Conference (Cyprus), Central Bank of Ireland Workshop on "Banking, Credit and Macroprudential policy", and seminar participants at the Federal Reserve Board (Washington), Banque de France, Bank of Portugal, National Bank of Romania and the European Central Bank for their helpful comments and suggestions. Project supported by a 2018 Leonardo Grant for Researchers and Cultural Creators, BBVA Foundation. This project has received funding from the European Research Council (ERC) under the European Union's Horizon 2020 research and innovation programme (grant agreement No 648398). Peydró also acknowledges financial support from the PGC2018-102133-B-I00 (MCIU/AEI/FEDER, UE) grant and the Spanish Ministry of Economy and Competitiveness, through the Severo Ochoa Programme for Centres of Excellence in R\&D (SEV-2015-0563). The opinions in this paper are those of the authors and do not necessarily reflect the views of the European Central Bank or the Eurosystem.
} 


\section{Introduction}

Public regulation is widespread in modern societies, with governments prevalently intervening throughout the marketplace (Stigler, 1971; Tirole, 2014). However, enforcement of policy requires effective supervision (Laffont and Tirole, 1993). Supervision of banks is considerably more challenging than that of other industries (Dewatripont and Tirole, 1994; Myers and Rajan, 1998) due to the opacity and complexity of bank assets and due to lobbying and revolving doors, especially from larger banks (Morgan, 2002; Johnson and Kwak, 2010; Acemoglu and Robinson, 2013).

Academics and policy-makers agree that the financial crisis highlighted the limitations of the prevailing supervisory framework in preventing excessive risk-taking and ensuring the resilience of the banking system to large adverse shocks. This fostered a debate on changes to the institutional setting (Dewatripont and Freixas, 2012; Freixas, Laeven and Peydró, 2015), including the potential benefits of supranational supervision (Draghi, 2018). On the one hand, local (national) supervisors may have better information than more centralised (supranational) supervisors; but, on the other hand, they may be more lenient or prone to local capture (because of different incentives). Supranational supervision might therefore potentially be more independent, avoiding national biases and collusion, while also having access to broader resources (Hayek, 1945; Agarwal et al., 2014; Carletti et al., 2016; Hakenes and Schnabel, 2014; Laffont and Martimort, 1999; Repullo, 2017; Constâncio, 2013).

In brief, we show that supranational supervision reduces credit supply to firms with very high exante and ex-post credit risk, while fostering the supply of credit towards firms without loan delinquencies. Economic and statistical effects are stronger for banks operating in stressed countries. Exploiting heterogeneity across banks, we conclude that the mechanism underlying the results is connected to higher quantity and quality of (human) resources available to the supranational supervisor rather than to the changes in incentives due to the new institutional setting. We also find that centralised supervision offsets excessive bank risk-taking induced by a more accommodative monetary policy, but not the more productive risk-taking. The euro area provides an excellent setting for empirical identification, as we can exploit: (i) the institutional change leading to the centralisation of bank supervision for some banks; (ii) a new, unique, supervisory dataset consisting of the credit registers for 15 countries; (iii) monetary policy surprises over a period of unprecedented monetary policy action; (iv) cross-country variations in terms of financial constraints and also in supervision (euro area vs. non-euro area EU countries).

A crucial contribution to the literature of our paper is to empirically evaluate whether - and why supervisory authorities (national vs. supranational) can influence the quality and quantity of credit supplied by banks (excessive vs. productive risk-taking), and their interaction with the stance of monetary policy. Moreover, we find that the mechanism driving the results is more consistent with broader and better (human) resources available to the supranational supervisor (human capital 
accumulation, e.g. Gennaioli, LaPorta, Lopez-de-Silanes and Shleifer, 2013) rather than with different incentives between local supervisors and the new supranational institution (e.g. King and Levine, 1993; Hall and Jones, 1999; and Acemoglu, Johnson, and Robinson, 2001 and 2005). Another key contribution of our paper is to show that using multiple credit registers - for the first time in the literature, to our knowledge - is essential for achieving external validity. Literature has, in fact, exclusively analysed all banking (including macro-finance) questions using single credit registers. Our results on supervision show substantial cross-country heterogeneity suggesting that the use of multiple credit registers is crucial for the external validity of the results obtained. In the remainder of the Introduction, we provide a more detailed preview of the paper and discuss the novelty of our paper in relation to the literature.

Preview of the paper. In this paper we analyse the impact of banking supervision on the supply of credit, and its interactions with monetary policy. More specifically, we analyse whether transferring supervisory responsibilities to a supranational entity matters for bank credit supply and risk-taking. Moreover, since monetary policy easing may induce banks to change their risk bearing capacity and risk appetite, as indicated by the risk-taking channel of monetary policy (Adrian and Shin, 2010), we also analyse the interactions between supervision and monetary policy.

Banking supervision involves the monitoring of banks to evaluate whether they comply with banking regulation or whether they are engaged in unsafe risk practices and, if so, whether they take appropriate actions to correct such practices (see e.g. Eisenbach et al., 2017). Banks are complex and potentially opaque and, hence, difficult to supervise (Myers and Rajan, 1998; Morgan 2002). As the level of complexity increases with bank size, very large banks require more and better resources for effective supervision (Eisenbach et al., 2017; Gai et al., 2019).

Bank supervisors might be prone to regulatory capture (Johnson and Kwak, 2010; Igan and Lambert, 2019). The "revolving doors" between supervising authorities and supervised banks, the intense lobbying activities, and the disproportionate size of banks in a given country may lead local supervisors to pursue the private interests of the regulated industry and be more lenient towards banks. Note that the size of the bank might play a crucial role and that this is a relative concept, as in a small country, the largest bank may not be very large in absolute terms, but (relative to the country) still be too big to fail and hence have disproportionate power and influence. In the empirical analysis we will address this issue by exploiting different measures of bank size.

Local supervisors may also be more lenient towards weak banks, as bank failures can have large negative consequences on the local economy as well as on their reputation (Kane, 1989; Dewatripont and Maskin, 1995; Mishkin 2001; Rochet, 2009; Martynova, Perotti and Suarez, 2019). In the empirical analysis we will use bank NPL as a proxy for bank weakness. This is because asset quality has been a major problem and a supervisory priority in Europe, with the total amount of non- 
performing exposures reaching a peak of more than $€ 1$ trillion at the end of 2014 and only gradually (albeit steadily) declining thereafter.

We exploit 15 European credit registers comprising a unique confidential granular dataset collected in the context of the preparatory phase of the AnaCredit project by the European System of Central Banks. This represents the only loan-level dataset available for many countries, covering both Euro area and non-Euro area European countries. Data frequency is biannual, covering loans to nonfinancial firms over the period from June-2012 to December-2017. The total number of observations is large: more than 280 million observations. ${ }^{1}$ We collapse our big data at the bank-borrower-time level, with information on e.g. loan volume, bank size, NPL, borrower risk and industry. Our dataset includes granular information on exposures in default, defined as loans in arrears over at least 90 days, which we use to construct measures of borrower risk. This information is crucial for investigating banks' incentives for gambling for resurrection via loan ever-greening (see e.g. Rajan, 1994; Caballero, Hoshi and Kashyap, 2008).

Given the significant cross-country heterogeneity in the euro area, we analyse separately two groups of countries: "stressed" and "non-stressed". ${ }^{2}$ In addition to institutional and structural differences, the group of stressed countries was particularly affected by the sovereign debt crisis of 2010-2014, resulting in higher borrower risk and also in disproportionate holdings of low quality legacy assets. This is important as banking theory (e.g. Freixas and Rochet, 2008) argues that there are higher incentives for excessive risk-taking (e.g. gambling for resurrection via loan ever-greening) when there are weaker fundamentals, e.g. in crisis times or periods with high financial distress. Moreover, we exploit information on non-euro area European countries' credit registers to investigate the robustness of our findings in the form of a placebo test, since there was no change in the institutional setting of bank supervision in those countries.

The sample period covers a key institutional change in Europe. In November 2014, the Single Supervisory Mechanism (SSM) became operational, a crucial step towards the European Banking Union. We assess the effects of this institutional change by exploiting the associated heterogeneity in the time and cross-sectional dimension, since the change affected only a subset of euro area banks. Supranational banking supervision through the SSM inherited several prudential tools from local

\footnotetext{
${ }^{1}$ The actual number of observations that we use in the estimation is lower reflecting the cleaning of data, the collapse of the data at bank-borrower-time level (e.g. there are multiple loans from the same bank to the same firm in the same period in the original data), as well as different controls in the empirical strategy (e.g. different fixed effects). See Section 2.

${ }^{2}$ Notice that, in the context of the euro area analysis, research and policy assessments are normally conducted by grouping countries into these two exact categories. We define as "stressed" countries those whose 10-year sovereign yield exceeded 6\% (or, equivalently, four percentage points above the German yield) for at least one quarter in our sample period. Specifically, throughout the paper, the term stressed countries refers to Italy, Spain, Ireland, Portugal and Slovenia; non-stressed countries are instead Germany, France, Austria, Belgium, Malta, Lithuania, Latvia and Slovakia. We also exploit non-euro-area countries, in particular Romania and Czech Republic (see in next pages). Due to confidentiality constraints, we can only show the results for groups of countries (stressed and non-stressed) but not country-specific (nor bank-specific) results.
} 
authorities of participating Member States - the National Competent Authorities (NCAs) - which can be activated to ensure the safety and soundness of the European banking system. Moving responsibilities from the national to the supranational authority comes with a potentially different set of incentives between the local and supranational authority that could, for example, reduce the supervisory capture or supervisory forbearance mentioned above. But there are other changes associated with the new institutional setting. The first one is related to the potentially more limited information available to the new supervisory entity due to the reduced geographical and cultural proximity. The second one is instead connected to the potentially enhanced quantity, quality and organisation of human capital employed at supranational level. Relying on a bigger number of supervisors, recruited from a broader market while offering more competitive compensation schemes, could allow for more effective supervisory strategies (Dal Bó et al., 2013). At the same time, further enhancements of the organisation of the supervisory process could come through the use of Joint Supervisory Teams (JSTs), which include staff from the European Central Bank (ECB) and from national supervisors, thereby ensuring cooperation and coordination between the centralised and local supervisors. Moreover, this setting allows not only for cross-national learning from best practices adopted in different countries but also for a more comprehensive view of the activities of internationally active banks.

During our sample period, there have also been unprecedented monetary policy actions with the introduction and subsequent recalibrations of (targeted) long-term liquidity provision operations, quantitative easing programmes and negative interest rate policy (Rostagno et al., 2019). In order to measure the impact of monetary policy on credit supply, we use the surprise component of each policy action using high-frequency movements across a wide spectrum of maturities of the risk-free interest rates around official policy meetings of the ECB Governing Council.

Exploiting the granularity of data at the borrower-bank-time level is crucial to exhaustively control for multiple sources of unobserved heterogeneity when analysing bank risk-taking. First, as different banks (e.g. with different risk appetite) may be matched with different borrowers (e.g. in terms of creditworthiness), bank*firm fixed effects are essential to control for persistent (non-random) bankfirm lending relationships. Moreover, firm*time fixed effects control exhaustively for time-varying unobserved borrower fundamentals, notably firm-level credit demand, growth opportunities and risk. As firm*time fixed effects require firms to borrow from at least two banks in a given period, we also use sector*time (and country*time) fixed effects to control for time-varying firm fundamentals using all firms in our sample. Since banks have different fundamentals and balance sheet characteristics, we also control for bank*time fixed effects, which are crucial as they fully capture not only observed time-varying characteristics such as bank profits, capital and liquidity, but also unobserved ones (e.g. business models and risk appetite). Overall, only a credit register allows for this type of identification. Moreover, as the effects may be different across countries, multiple credit registers are critical for 
external validity. Furthermore, monetary policy surprises and changes across time and banks in the institutional setting of banking supervision are key for identification. The euro area setting offers all these crucial elements for the identification of the main questions of the paper.

Our robust results show that supranational (versus local) banking supervision reduces the supply of credit towards firms with very high ex-ante risk (worse credit history/current defaults), and also towards firms that tend to default more ex-post, i.e. firms with previous and current delinquent loans which do not improve over time, consistently with a reduction in excessive bank risk-taking associated to gambling for resurrection via loan ever-greening. At the same time, centralised supervision increases the supply of credit to firms without delinquent loans and has no effects (statistically and economically) on the supply of credit towards more productive firms, proxying for "good risk-taking". In our analysis, excessive risk-taking does not mean a level of risk-taking over and above the theoretically optimal one, but rather an increase in the supply of credit towards firms with a large share of their loans in default and not improving over time. This particular bank risk-taking has a negative connotation in theoretical models (e.g. Rajan, 1994; Caballero, Hoshi, Kashyap, 2008) and in empirical banking (Akerlof et al., 1993; Freixas and Rochet, 2008); and moreover in our analysis we contrast it with credit supply to more productive firms (proxied by the ratio between labour productivity and average personnel costs).

Estimated effects are economically strong and quantitatively larger in stressed countries. Centralised bank supervision leads to a reduction in credit supply to a firm with a 1 standard deviation decrease in credit quality by around $8 \%$ in stressed countries and $5 \%$ in other countries, respectively. Moreover, the reduction in risk-taking is not affected by the level of bank risk/weakness (proxied by ex-ante NPL). The effects are substantially stronger for very large banks (e.g. over Euro 300, 400, 500 billion of total assets, or even beyond), but are not statistically or economically significant for the largest bank in each country (note that, as some countries are small, the largest bank would be considered as large relatively to the country but not in absolute terms). Taking all these results together, our analysis suggests that the mechanism underlying the enhanced effectiveness of the centralised supervision in reducing excessive risk-taking is driven by broader and better human resources available to supranational supervision (capacity hypothesis) rather than by differences in incentives between supranational vs. local supervisors (incentive hypothesis).

We conduct a series of robustness checks to assess the internal and external validity of our results. Effects on excessive bank risk-taking are similar if we only include banks around the threshold to be centrally supervised (i.e., 3 banks above and 3 below the threshold, which is the minimum number of banks supervised by the SSM in a country) and are completely absent for banks operating in European Union countries outside the euro area (therefore not subject to the change in the institutional setting of bank supervision). Moreover, although the official establishment of the central supervisory authority took place in November 2014, banks had information on the regulatory change since October 2013, 
i.e. when the SSM Regulation was published and a comprehensive assessment of the supervised institutions (comprising an asset quality review and a stress test) was announced. Therefore, we test for the actual date since when centrally supervised banks changed their risk-taking behaviour. Our results show that the change in the behaviour of the credit supply of centrally supervised banks operating in stressed countries took place when the supranational authority became operational.

Finally, we study the interaction between supervision and monetary policy. We find that monetary policy easing (identified through monetary policy surprises) increases credit supply to firms with very high ex-ante (and ex-post) credit risk, consistent with more excessive risk-taking due to monetary policy. However, the change in the allocation of responsibilities in supervision towards a supranational entity limits this (more excessive) bank risk-taking. Results are significant for all banks, but with stronger economic effects for the very large banks. Moreover, the decrease in risk-taking induced by centralised supervision following a monetary policy easing does not lead to a compression in credit supply to more productive firms. These results emerge as particularly important as they show that, while expansionary monetary policy leads to some risk-taking through an easing in financing conditions, which may be an intended policy consequence (Adrian and Shin, 2010), supranational banking supervision reduces the more excessive risk-taking, but not the more productive one.

Contribution to the literature. We now summarize in more detail our contribution to the literature, which spans banking supervision, the bank-lending and risk-taking channels of monetary policy and, more generally, the credit channel.

We start with our contribution to the literature on banking supervision. In a path-breaking paper, Agarwal et al. (2014) analyse supervisory decisions of U.S. banking federal versus state supervisors and find that federal regulators are systematically tougher than state regulators on reporting past risk. ${ }^{3}$ Our paper addresses a different but related question, thereby providing novel insights. We show how supranational supervision heterogeneously influences credit supply (e.g. reducing credit supply to firms with very high credit risk, while increasing credit supply to firms without delinquent loans), with associated consequences on the real economy via firms' credit availability.

There is a growing recent literature focusing on the link between prudential supervision and bank lending decisions. Specifically, various studies conclude that stricter regulatory oversight can lead to an expansion in lending (Granja and Leuz, 2017) and a reallocation of loans away from firms with negative equity (Bonfim et al. 2019). In general, a reduction in supervisory attention leads to an increase in banks' willingness to take risk (Kandrac and Schlusche, 2019). Focusing on heterogeneity across banks, some studies find that because large banks receive more attention from supervisors they tend to hold less risky loans and are less sensitive to industry-specific fluctuations (Hirtle, Kovner and

\footnotetext{
${ }^{3}$ In theory, supranational supervision may overcome coordination failures connected to the supervision of the large multinational banks (Calzolari et al. 2019, Beck et al. 2013); in addition, the allocation of supervisory powers and responsibilities may also influence bank decisions (Dell'Ariccia and Marquez, 2006).
} 
Plosser, 2018; and Eisenbach, Lucca and Townsend 2016). Our paper provides evidence not only on credit supply and risk-taking, but also suggestive evidence on the underlying mechanism through which supervision affects banks' decisions. Our results are consistent with the availability of broader and better (human) resources to central supervisors (human capital accumulation, see e.g. Gennaioli, LaPorta, Lopez-de-Silanes and Shleifer, 2013) rather than with different incentives of the new supranational institution (King and Levine, 1993; Hall and Jones, 1999; and Acemoglu, Johnson, and Robinson, 2001 and 2005). In this sense, the implications of our analysis go beyond the particular setting of supervision, providing more general insights on why (new) institutions matter.

We also contribute to the large literature on the bank lending and risk-taking channels of monetary policy (e.g. Bernanke and Blinder, 1988 and 1992; Kashyap and Stein, 2000; Jimenez, Ongena, Peydró and Saurina, 2012 and 2014; Dell'Ariccia, Laeven and Suarez, 2017; Drechsler, Savov and Schnabl, 2017) by showing how the transmission of monetary policy through credit supply and bank risk-taking depends on supervision. To the best of our knowledge we are the first to show that monetary policy and bank supervision tend to complement each other. Importantly, the reduction in banks' risk-taking driven by centralised supervision is concentrated on the more (excessively) risky exposures, but not in more productive sectors ("good risk-taking”).

More generally, a key contribution (that goes beyond bank supervision, monetary policy and risktaking) consists of analysing all economic questions posed in our paper using multiple credit registers. This is crucial not only for identification but also for assessing the heterogeneous effects across countries. We show that some important research and policy questions - although not all of them yield very different results depending on the group of countries analysed. We find, for example, similar effects for the largest banks across stressed and non-stressed countries, but substantial crosscountry differences in the effects of supervision on risk-taking. External validity is important for testing theories and policy analysis, and local estimates from single countries cannot always be generalised. The large empirical literature on the credit and bank lending channels (for banking, macro-finance, and monetary policy) has analysed all questions using single credit registers (e.g. Mian, 2006; Khwaja and Mian, 2008; Paravisini, 2008; Amiti and Weinstein, 2011; Schnabl, 2012), with previous literature even working with more aggregate data. ${ }^{4}$ To our knowledge this is the first study using multiple credit registers.

The rest of the paper is organized as follows. Section 2 presents the data used in the empirical analysis. In Section 3 we discuss the empirical strategy and results, including the associated mechanism and the interactions with monetary policy. In Section 4 we offer concluding remarks.

\footnotetext{
${ }^{4}$ Aggregate data have severe limitations when the scope of the analysis is to identify causal relationships. For example, using only bank-level data (as done, for example, in the highly influential work by Kashyap and Stein, 2000) it is not possible to fully identify changes in bank lending driven by demand and supply conditions.
} 


\section{Big Data}

The analysis uses a unique confidential granular credit dataset collected in the context of the preparatory phase of the AnaCredit project by the European System of Central Banks. Importantly, this is the only credit register dataset available for more than one country and it covers both euro area and non-euro area European countries. The euro area countries included are: Austria, Belgium, Germany, Spain, France, Ireland, Italy, Lithuania, Latvia, Malta, Portugal, Slovenia and Slovakia. Some countries are excluded from the analysis due to data quality and availability issues (these are Ireland, Latvia, France, Malta and Slovenia). The European countries outside the euro area included in the dataset are the Czech Republic and Romania.

Data collection is biannual and covers the period from June-2012 to December-2017. The total number of observations is very large: more than 280 million observations. This makes the dimension of the dataset unique and it thereby represents the most comprehensive dataset on loan contracts used in empirical banking, as previous analysis has been conducted using a single credit register. Moreover, the dataset includes information on important bank and borrower characteristics such as credit volume (including both drawn and undrawn committed credit), ex-post defaults, ex-ante risk, the sector of activity of the borrowers, bank size and NPL ratios.

Table 1 shows, for each country, the reporting threshold of the individual credit register, the initial number of observations available in the dataset and the final number of observations remaining after cleaning and harmonising the data by dropping inconsistent information and reporting errors. ${ }^{5}$ Moreover, the dataset is restricted to exposures to non-financial corporations and to (drawn and undrawn) lending, dropping debt securities. Finally, we harmonise the unit of observation to borrowerbank-time, as some credit registers do not report loan-bank-time level data.

Given the significant heterogeneity in the euro area economies, we conduct the empirical analysis separately for two groups of countries: financially "stressed" (Italy, Portugal, and Spain) and "nonstressed" (Austria, Belgium, France, Germany, Lithuania and Slovakia). We define as "stressed" - that is, subject to high sovereign stress - countries whose 10-year sovereign yield exceeded $6 \%$ (or, equivalently, four percentage points above the German yield) for at least one quarter in our sample period. In addition, we test the robustness of our results using a placebo test on the two non-euro area EU countries in our data set which did not experience a change in the institutional setting of banking supervision.

\section{[Insert Table 1 here]}

\footnotetext{
${ }^{5}$ To be precise, we drop banks with less than 100 borrowers, banks for which information on borrower quality is missing for more than half the observations and banks where more than $90 \%$ of exposures are reported as nonperforming.
} 
Table 2 reports the descriptive statistics for the main variables used in the empirical analysis over the available sample for the two groups of countries. Significant cross-country heterogeneity emerges when looking at the average loan volumes (the total loans and credit lines at the borrower level in euro thousands) with the credit granted in stressed countries being substantially lower than the one in nonstressed countries: 500 vs. 1700 thousand euro, respectively. This difference in part reflects the higher reporting thresholds in non-stressed countries (as reported in Table 1).

Borrower quality indicates, for each borrower, the ratio between credit exposures in arrears and total credit exposures. The definition of arrears is homogenous across countries and refers to the delayed principal amount and/or the delayed interest payments that are past due more than 90 days. In line with the difference in the economic performance of the two groups of countries, the mean default frequency is larger for stressed countries (5\%) than for non-stressed countries (3\%). Centralised supervision is a dummy variable that takes value one for banks supervised at supranational level after November 2014, and zero for banks supervised at country level. Monetary policy shocks are the first principal component of the monetary policy surprises obtained from the high-frequency intraday yields at different maturities during all dates of policy announcements covered in the sample, and are extracted from the Euro Area Monetary Policy Event-Study Database - EA-MPD (see also Section 3 for more details). The negative average values indicate that the sample period is characterised by more accommodative policy even though it still covers a broad range of easing and tightening events (see Figure 3 for more details). The NPL ratio measures, for each bank, the share of non-performing loans to total loans. This measure is substantially higher in stressed countries than in non-stressed countries. The average bank in stressed countries has an NPL ratio of about $20 \%$. The picture is completely different for the banks operating in non-stressed countries, where the NPL ratio is about $5 \%$ with also a much smaller standard deviation.

Finally, the table also shows summary statistics for the two main variables used in the empirical analysis to proxy for bank size. The first one is the market share of the bank in each sector (Size). The second one is a dummy variable capturing possible non-linearities for very large banks (Large). More precisely, this dummy variable takes a value of 1 if the total assets of the bank are larger than Euro 500bn, i.e. about the size of Lehman Brothers when it collapsed in September 2008. ${ }^{6}$ Productivity is defined as the ratio between labour productivity (measured as the ratio of value added over number of employees) and average personnel costs and represents a cost-adjusted measure of sectoral labour productivity for each sector in each country. The table shows that on average labour productivity is lower in stressed countries. More specifically, the value added generated by an average employee in non-stressed and stressed countries exceeds the employee's cost by around 240 times and 220 times, respectively.

\footnotetext{
${ }^{6}$ In the analysis we will investigate the sensitivity of the results to changes in the threshold used for total assets in the definition of this dummy variable.
} 


\section{[Insert Table 2 here]}

\section{Empirical analysis}

This section presents the empirical strategy and the results of the paper. It is divided into four subsections. In the first subsection, the analysis focuses on the effects of the institutional setting of banking supervision, and the associated allocation of responsibilities (centralised vs. country-level supervision), on lending decisions and risk-taking of euro area banks. The second and third subsections focus on the robustness analysis and the mechanism underlying our main findings, respectively. The last subsection concentrates on the interaction between banking supervision and monetary policy.

\subsection{Risk taking and banking supervision}

In this subsection we outline the empirical strategy and present our findings on the implications for bank risk-taking behaviour of the institutional design of supervision. We ask whether the level of direct supervision - either centralised (i.e. conducted by a supranational authority) or local (i.e. conducted by a national regulatory authority) - influences bank credit supply.

On the $4^{\text {th }}$ of November 2014, centralised supervision became operational in the euro area through the establishment of the Single Supervisory Mechanism (SSM). Since then, while the local authorities of participating countries - the National Competent Authorities (NCAs) - continue to supervise banks that are classified as "less significant", the European Central Bank (ECB) is responsible for direct supervision over the so-called "significant institutions". For a bank to be included in the list of significant institutions supervised by the SSM it should respect the following criteria: (i) total assets exceed $€ 30$ billion; (ii) the ratio of total assets over GDP of the participating Member State exceeds 20\%; (iii) the bank is among the three largest credit institutions in a participating Member State; (iv) total assets exceed €5 billion and the ratio of its cross-border assets in more than one other participating country to its total assets is above 20\%; (v) the institution has requested or received funding from the European Stability Mechanism or the European Financial Stability Facility.

Supranational banking supervision through the SSM inherited several prudential tools from national supervisory authorities which can be activated to ensure the safety and soundness of the European banking system. These tools include carrying out supervisory reviews (including stress tests), conducting on-site inspections and investigations, granting or withdrawing banking licences, authorising banks' acquisitions of qualifying holdings, ensuring compliance with EU prudential rules, setting higher capital requirements ("buffers") in order to counter financial risks, and imposing corrective measures and sanctions. There are however potential improvements in the effectiveness of the overall supervisory process, following the new institutional setting that are connected to the reallocation of responsibilities among supervisory authorities. 
On the one hand, the new competent authority is likely to have a different incentive structure which could limit the so-called regulatory capture. First, the local supervisor might have a different objective function which attributes a higher importance to the stabilizing effect of bank lending on the local economy, and therefore be more reluctant to promote an aggressive cut in risk taking by banks, which would increase their resilience at the cost of firm failures with the associated implications for employment. Moreover, local supervisors may also be more susceptible to political pressure in the same direction. Second, given the increasing share of banks' cross-border activities, local supervisory authorities are likely to be oriented towards national borders thereby not fully internalising the crossborder transmission of risks, ultimately leading to home-bias and more lenient supervision. Third, local supervisors might be more vulnerable to agency problems either because supervised banks are more likely to be a future career option ("revolving door") or because they are more susceptible to lobbying activities. See e.g. Laffont and Tirole, 1991; Laffont, 1999; Agarwal et al., 2014; Repullo, 2017; Igan and Lambert, 2019.

On the other hand, the central supervisor is also likely to benefit from broader and more efficient resources (Draghi, 2018). The new supranational authority relies on a larger number of highly specialized employees recruited from a broader market while offering more competitive compensation schemes, which should allow for more effective supervisory practices. Indeed, simple neoclassical models imply that productivity increases with wages. Moreover, extensions incorporating various distortions strengthen this finding, as paying relatively higher salaries reduces shirking due to the higher cost of being fired (Shapiro and Stiglitz, 1984), attracts higher skilled employees (Weiss, 1980) and improves motivation also when working in teams (Akerlof, 1982). Consistently, recent empirical literature shows that more attractive financial incentives increase productive also for civil servants (e.g. Dal Bó et al., 2013). In parallel, the cross-national dimension of centralised supervision allows it to set up more effective supervisory strategies by adopting and harmonising the best practices from different countries and by having a more complete view of the activities of cross-border banks. In other words, the improvements might be related to the quantity and quality of the human capital employed at supranational level as well as to the specific organisation of the supervisory process that ensures cooperation and coordination between the centralised and local supervisors. In practice, this cooperation is enforced through Joint Supervisory Teams (JSTs) including staff from the ECB and from national supervisors.

With this change in the institutional setting in mind, the main question we want to answer is the following: does centralised supervision, as opposed to country-level supervision, influence bank credit supply and risk-taking behaviour? Econometrically, the model specification that we use to answer this question is the following:

$$
\text { Loans }_{b, f, t}=\alpha^{F E}+\delta B Q_{f, t-1}+\theta \operatorname{Sup}_{b, t-1}+\lambda\left(B Q_{f, t-1} \times \operatorname{Sup}_{b, t-1}\right)+\epsilon_{b, f, t}
$$


The dependent variable ( oans $_{b, f, t}$ ) is the (log-)credit granted (drawn and undrawn) by bank "b" to firm " $\mathrm{f}$ " at time "t". The explanatory variable $B Q_{f, t-1}$ is a measure of borrower quality constructed for each borrower as the ratio between credit exposures in arrears and total credit exposures. This measure ranges between zero - when firms have no arrears - and one - when all of the firm's exposures are in arrears. ${ }^{7}$ In addition, the model also includes a variable that accounts for the level of supervision of each individual bank. More specifically, $\operatorname{Sup}_{b, t}$ is a dummy variable that takes value 1 for banks directly supervised by the SSM (bank $b \in S S M$ ) after November 2014 and zero otherwise:

$$
\operatorname{Sup}_{b, t}=\left\{\begin{array}{cc}
1 & \text { if } b \in \text { SSM and } t \geq \text { November } 2014 \\
0 & \text { otherwise }
\end{array}\right.
$$

Moreover, the specification also includes an interaction term between the level of supervision and borrower quality $\left(B Q_{f, t-1} \times \operatorname{Sup}_{b, t-1}\right)$. The main hypothesis we want to test is whether the risktaking behaviour of banks is affected by the change in the allocation of responsibilities between national and supranational supervisors. If banks reduce credit supply to borrowers with lower credit quality once they become supervised by the SSM, then we expect a negative coefficient on the interaction term $(\lambda<0)$.

The empirical analysis uses an extensive set of fixed effects to control for possible confounding factors. In case they are not absorbed by other fixed effects, all specifications include country-time fixed effects accounting for all possible observed and unobserved heterogeneity due to countryspecific factors. These comprise differences in the macro outlook, including demand conditions varying at country level, as well as other potential (time-varying) differences across countries. Bank or bank*time fixed effects control for time-invariant and time-varying unobserved bank-specific characteristics, respectively, e.g. business models or balance sheet characteristics (Jiménez et al., 2014).

A different set of fixed effects is used to identify whether a change in lending dynamics is driven by supply (bank-related) or demand (firm-related) factors. Firm or firm*time fixed effects control for firm-specific characteristics. Importantly, considering firm*time fixed effects translates into controlling for time-varying unobserved firm characteristics (including firm-level demand and risk factors), thereby ensuring that the results capture supply side variation (see Khwaja and Mian, 2008). A possible caveat of including firm*time fixed effects is that this restricts the analysis to firms with multiple lending relationships. Figure 1 shows the share of borrowers with multiple lending relationships, ranging from 10 to just below $50 \%$. Panel B of the figure shows that in terms of credit volume the share of multiple lending relationships is significantly higher, ranging from around 40 to close to $90 \%$. In order to capture also firms with single lending relationships, we also estimate

\footnotetext{
${ }^{7}$ An alternative is to construct a dummy variable that takes the value one if a firm has a least one exposure in arrears, and zero otherwise. Results do not change.
} 
specifications using sector*time - rather than firm*time - fixed effects to account for unobserved heterogeneity in demand and risk across sectors. The sectors of economic activity are grouped according to the 2-digit NACE2 industrial classification (i.e. we have 99 sectors).

\section{[Insert Figure 1 here]}

Finally, bank-firm fixed effects control for possible (time-invariant) non-random matching between lenders and borrowers. The inclusion of these fixed effects implies that our estimates are identified by the time variation in lending within a bank-firm relationship. An example for why these controls are important is that a bank's ex-ante assessment of the creditworthiness of a borrower may persistently differ from that of another bank: a bank might simply believe that a firm is relatively safe (or have private information on it) and thereby be more willing to lend to it. At the same time, a firm might have a persistent preference towards a specific bank. That is, these bank-firm fixed effects account for lending relationships (Freixas and Rochet, 2008).

Note that in our empirical model we exploit the change in the supervisory process from national to supranational, for treated versus non-treated banks (the latter remained supervised at the country level), and control also for bank*time fixed effects (in addition to the other fixed effects). Given that the key variable of interest is at the bank level, we cluster standard errors at bank level for the benchmark regressions. ${ }^{8}$ The results are reported in Table 3. The different set of fixed effects used in each specification is reported at the bottom of the table.

\section{[Insert Table 3 here]}

The estimated coefficient for the change in the sensitivity of bank credit supply to a deterioration in borrower quality (BQ) is negative and significant in all specifications. The reduction in lending to ex-ante riskier firms is amplified after banking supervision becomes centralised (i.e., the interaction term shown in the table is negative). More in detail, the coefficients in columns 1 and 5 of Table 3 indicate that the centralisation of bank supervision leads to a reduction in loan supply to a firm with maximum ex-ante risk by $43 \%$ in stressed countries and $36 \%$ in other countries. Note that this result compares firms with credit quality at opposite extremes. For a 1 standard deviation change in credit quality, the corresponding figures are close to $8 \%$ in stressed countries and $5 \%$ in other countries, respectively. These results are based on specifications which control for firm demand at the country*time and sector*time level so that they include also firms with single lending relationships. In Columns 2 and 6 we instead control fully for unobserved heterogeneity at the firm*time level to better identify credit supply with heterogeneous results across country groups. For stressed countries, while the size of the coefficient on the interaction term $(\lambda)$ is reduced compared to the previous specification

\footnotetext{
${ }^{8}$ Results are robust to double clustering at bank and firm level.
} 
its magnitude and statistical significance remain high. Conversely, for non-stressed countries, the coefficient in this specification is not economically or statistically significant. ${ }^{9}$

Notice that the results in Table 3 refer to the relative impact of centralised banking supervision on loan supply to firms with different levels of credit risk, but they are silent on its impact on overall lending. This is because the fixed effects used in the empirical analysis to exhaustively control for all other sources of observed and unobserved heterogeneity absorb also the variability that would be used to identify $\theta$ in equation (1), since $\operatorname{Sup}_{b, t-1}$ varies at the bank-time level. Estimating a model which includes bank instead of bank*time fixed effects, our results (see Table A.1) indicate that centralised supervision does not impact overall credit supply but rather its composition.

Having established that centralised supervision leads to a decrease in credit supply to borrowers with lower credit quality, as proxied by worse credit history, we investigate whether the ex-post performance of loans is also better for centrally supervised banks. In practice, this amounts to substituting the ex-ante measure of borrower quality in equation (1), $B Q_{f, t-1}$, with the ex-post measure $B Q_{f, t+1}$. In this case, a negative sign of the interaction term $\left(B Q_{f, t+1} \times S u p_{b, t-1}\right)$ would indicate that centralised bank supervision results in a contraction in credit supply towards firms that turned out to default more ex-post. The results shown in columns 3 and 4 for banks operating in stressed counties and column 7 for banks operating in non-stressed countries support this hypothesis: the shift from local to supranational supervision leads banks to originate less credit supply towards firms with higher ex-post realised defaults. ${ }^{10}$ Results for non-stressed countries are weaker and less robust, in particular when controlling for firm-level risk and demand (column 8). Overall, the results are very similar to ex-ante risk, suggesting that centralised supervision largely acts by reducing excessive forbearance and loan ever-greening rather than just the provision of credit to troubled firms with temporary liquidity problems.

While the reduction in risk-taking due to centralised banking supervision contributes to improve banks' resilience, its broader macroeconomic impact is not necessarily positive if riskier firms are also those contributing more to economic growth. It is therefore important to assess whether the change in the supervisory setting also leads to a decrease in credit supply to more productive firms. This is implemented in the specification shown in equation (2) below, where $\operatorname{Prod}_{c, s, t}$ is a cost-adjusted measure of sectoral labour productivity for each sector in each country. A negative coefficient on the interaction term $\operatorname{Prod}_{c, s, t} \times \operatorname{Sup}_{b, t-1}$ would imply that centralised supervision leads to a decrease in credit supply towards more productive firms.

\footnotetext{
${ }^{9}$ Importantly, our results do not change when we test for relevance of the differences in reporting thresholds across countries by estimating our model on a sample restricted to loan exposures above e.g. 350 thousand euro (results available upon request).

${ }^{10}$ Results are similar if we extend the horizon considered to identify ex-post defaults to 2 periods, which corresponds to 1 year (not reported).
} 


$$
\begin{aligned}
\operatorname{Loans}_{c, b, s, f, t}= & \alpha^{F E}+\operatorname{\rho Prod}_{c, s, t}+\theta \operatorname{Sup}_{b, t-1}+\delta B Q_{f, t-1}+\lambda\left(B Q_{f, t-1} \times \operatorname{Sup}_{b, t-1}\right) \\
& +\tau\left(B Q_{f, t-1} \times \operatorname{Prod}_{c, s, t}\right)+\sigma\left(\operatorname{Prod}_{c, s, t} \times \operatorname{Sup}_{b, t-1}\right)+\Omega X_{b, f, t-1} \\
& +\epsilon_{c, b, s, f, t}
\end{aligned}
$$

Table 4 confirms that centralised supervision reduces bank credit supply to ex-ante riskier borrowers $\left(B Q_{f, t-1} \times \operatorname{Sup}_{b, t-1}<0\right)$.

Crucially, banks' preference to lend to more productive firms is not influenced by the centralisation of bank supervision $\left(\operatorname{Prod}_{c, s, t} \times \operatorname{Sup}_{b, t-1}=0\right)$. These results hold independently of whether banks operate in stressed or in non-stressed countries. Note that the estimated coefficients tend to be positive, though small and not statistically significant, therefore, if anything, providing weak evidence that centralised supervision might actually lead to an increase in lending to more productive firms. ${ }^{11}$ Moreover, there is an interesting interaction between credit performance and the productivity of the sector where firms operate. While on average banks extend less lending to borrowers with higher credit risk $(\mathrm{BQ}<0)$, this effect is mitigated when firms operate in a more productive sector $\left(B Q_{f, t-1} \times \operatorname{Prod}_{c, s, t}>0\right)$. In other words this result indicates that, for a given level of firm riskiness, banks tend to extend more credit to those operating in higher value added sectors. This difference is relevant not only statistically but also economically. For the same level of risk, the lending to a firm operating in a sector with a level of productivity that is 1 standard deviation above the mean is found to increase by $5 \%$.

\section{[Insert Table 4 here]}

\subsection{Robustness}

In the wake of the financial crisis there has been a thorough revision of the regulatory framework for banking supervision. This is not a major concern for our results as the bulk of regulatory changes apply to all banks and not only to those who then became centrally supervised. In any case, since the actual implementation of such changes was (and to some extent is still being) gradually phased in, it partially overlaps with the process of institutional change that resulted in the establishment of centralised supervision in the euro area. Moreover, while the centralised supervisory authority became fully operational in November 2014, banks learned that they would become centrally supervised in October 2013, when the SSM Regulation was published. Since these factors could have already influenced bank behaviour, we further investigate the exact timing of the change in the risk-taking behaviour of centrally supervised banks. More specifically, we estimate equation (1) for alternative timings of the effective start of centralised bank supervision, thereby defining $\operatorname{Sup}_{b, t}$ as follows:

\footnotetext{
${ }^{11}$ These results do not depend on the particular measure of productivity that we use (not reported).
} 


$$
\operatorname{Sup}_{b, t}=\left\{\begin{array}{cc}
1 & \forall \mathrm{t} \geq 2013 \mathrm{H} 1, \ldots, 2015 \mathrm{H} 1 \\
0 & \text { otherwise }
\end{array}\right.
$$

Figure 2 reports the estimated coefficients for the interaction terms $B Q_{f, t-1} \times S u p_{b, t}$ estimated for the different periods based on a specification that includes the same fixed effects as in column 2 of Table 3. The chart documents the results for stressed countries since the coefficient of interest is not statistically (or economically) significant in the same specification for non-stressed countries. Results show that banks operating in stressed countries significantly reduced their credit supply towards firms with higher ex-ante credit risk (proxied by credit delinquencies) since 2014Q4. Importantly, the estimated coefficient for the impact of supervision on risk-taking ( $B Q \times$ Sup) up to $2014 \mathrm{H} 1$ is not significant in statistical or economic terms. On the contrary, results are significant since the operationalisation of centralised supervision in $2014 \mathrm{H} 2$.

\section{[Insert Figure 2 here]}

Our main results consider all credit commitments by banks therefore including both drawn and undrawn credit (e.g. credit lines) in order to fully capture lending decision by banks. However, one might wonder whether results would change in case only actually drawn credit is considered, i.e. the volume of loans outstanding. Table 5 shows that, although the main results would not qualitatively change, the size of the coefficient is reduced thereby highlighting the importance of taking into account the full volume of committed lending.

\section{[Insert Table 5 here]}

As discussed above, bank size is one of the main criteria used to define the set of institutions subject to centralised supervision. We therefore define a further robustness exercise where we focus the analysis on a subset of banks which, despite limited size heterogeneity, are assigned to different supervisory authorities. This subset includes the 3 largest locally supervised banks and the 3 smallest centrally supervised ones for each country. The choice of 3 banks is motivated by the fact that the regulation defines this as the minimum number of centrally supervised banks in each country. The results of this exercise are shown in columns 1-4 of Table 6. Results are strong and significant for the stressed countries only.

Despite the broad range of controls used in the analysis, a potential source of concern for our conclusion is that results might not be driven by the introduction of centralised supervision but rather by some correlated unobserved characteristics in the cross-section and the time dimension. If this were the case, one would expect to find the same results for banks with similar characteristics observed over the same time period but not subject to the centralisation of bank supervision. We therefore present a placebo test replicating the analysis shown in Table 3 for banks operating in European countries where bank supervision remained local (Romania and Czech Republic). Applying the criteria described above, we identify three banks in each of these countries which would be centrally supervised if the 
country were part of the SSM. Results reported in Table 6, column 5 and 6, show that there are no significant differences in behaviour between this set of banks and that which would anyway have remained locally supervised. In other words, banks operating in non-euro area countries did not experience any change in their risk-taking behaviour around the time when centralised supervision was introduced in the euro area.

\section{[Insert Table 6 here]}

\subsection{The mechanism}

Having established that centralised banking supervision leads to a reduction in (excessive) bank risk taking (without curtailing credit supply to more productive firms and supporting credit supply to firms without delinquencies), we exploit the mechanism underlying our main result by testing the relevance of two competing hypotheses.

The first one relates to the different incentive structures associated to each institutional setting whereby centralised supervisors are less likely to be captured by banks - the incentive hypothesis. The incentive structure of local supervisors might induce a more lenient attitude toward bank risk-taking, and this is likely to be less relevant for a supranational supervisor (Agarwal et al., 2014, Carletti, Dell’Ariccia and Marquez, 2016; Repullo 2017). More generally, new institutions may promote better economic outcomes via different incentives (e.g. King and Levine, 1993; Hall and Jones, 1999; and Acemoglu, Johnson, and Robinson, 2001 and 2005). At the same time, local supervisors might have superior information on banks' loan portfolios, including whether borrowers appear weak due to temporary liquidity constraints or are indeed insolvent (Hayek, 1945). In this case, more lenient behaviour by local supervisors might actually be desirable to the extent that it avoids costly defaults and the associated pro-cyclical contractionary effect.

The second main reason why centralised supervisors might be more effective in reducing bank excessive risk-taking is related to the broader and potentially better human resources available to them - the capacity hypothesis. The centralisation of supervision led to an increase in the resources available, with enhanced quantity, quality and organisation of human capital employed at supranational level, thereby relaxing possible capacity constraints. This argument is related to that in Romer and Romer (2000), where the superior information central banks have over market participants about the future state of the economy is attributed to the broader resources involved in forecasting. Our definition of capacity is broader than this, considering also that the centralised supervisor can recruit staff from a broader market, also offering more competitive compensation, and that its crosscountry perspective potentially allows for the set-up of more effective supervisory strategies based on the best practices adopted in different countries. As discussed above, recent empirical studies show that - also for civil servants - higher financial incentives are able to attract a larger and better applicant pool (Dal Bó et al. 2013). Moreover, the supranational supervisor allows for a more 
comprehensive assessment of the activities of large banks with a strong international presence. More generally, human capital accumulation is a key driver of economic outcomes (see e.g. Gennaioli, LaPorta, Lopez-de-Silanes and Shleifer, 2013).

In principle, there are likely non-linearities in the capacity required to supervise banks with different sizes, as very large banks are disproportionally complex due to their scope of activities and cross-border dimension. At the same time, the largest bank in each country is not necessarily large for the euro area as a whole, reflecting on different incentives for a local versus a supranational supervisor. Therefore, by exploiting different measures of bank size, as we have explained earlier in the paper and we discuss further below, we can disentangle the different mechanisms.

The specification used to test these hypotheses takes the following form:

$$
\begin{aligned}
\text { Loans }_{b, s, f, t}= & \alpha^{F E}+\beta_{1}\left(N P L_{b, t-1} \times B Q_{f, t-1} \times \operatorname{Sup}_{b, t-1}\right) \\
& +\beta_{2}\left(\text { Size }_{b, s, t-1} \times B Q_{f, t-1} \times \operatorname{Sup}_{b, t-1}\right) \\
& +\beta_{3}\left(\text { Large }_{b} \times B Q_{f, t-1} \times \operatorname{Sup}_{b, t-1}\right)+\Omega X_{b, f, t-1}+\epsilon_{b, s, f, t}
\end{aligned}
$$

Where bank size is proxied by the market share of the bank in each sector $\left(\operatorname{Size}_{\mathrm{b}, \mathrm{s}, \mathrm{t}-1}\right)$ and possible non-linearities for very large banks are captured by a dummy variable $\left(\operatorname{Large}_{\mathrm{b}}\right.$ ), which takes value 1 if the total assets of the bank are larger than Euro 500bn, i.e. about the size of Lehman Brothers when it collapsed in September 2008. Banks' non-performing loan ratio (NPL $\left.\mathrm{N}_{\mathrm{b}, \mathrm{t}-1}\right)$ is the volume of non-performing loans granted as a share of total lending for bank "b" at time "t-1". Notice that the vector $X$ contains all lower level interactions among $\mathrm{NPL}_{\mathrm{b}, \mathrm{t}-1}, \mathrm{BQ}_{\mathrm{f}, \mathrm{t}-1}, \operatorname{Sup}_{\mathrm{b}, \mathrm{t}-1}, \operatorname{Size}_{\mathrm{b}, \mathrm{s}, \mathrm{t}-1}$ and Large $\mathrm{b}_{\mathrm{b}}$. Moreover, we estimate the same specification for alternative definitions of the variable Large $_{\mathrm{b}}$ in Table 8.

The estimates in Table 7 show that the impact of centralised bank supervision on risk taking does not depend on bank NPL or a continuous measure of bank size. Differently, the reduction in risk taking due to centralised bank supervision is substantially stronger for the very large banks, most notably in stressed countries. ${ }^{12}$

\section{[Insert Table 7 here]}

We assess the robustness of these findings by estimating the same model using alternative definitions of "Large”, including banks with total assets exceeding Euro 200bn, 300bn, 400bn, and 500bn (results above this threshold are very similar). Moreover, we dig deeper into the mechanism that drives the results by assessing the role played by the largest bank in each country. Table 8 reports the estimated coefficients of the triple interaction $\mathrm{BQ}^{*}$ Sup*Large for stressed countries under these different

\footnotetext{
${ }^{12}$ Notice that the table clearly shows a robust result on a positive association between weak banks (the ones with higher NPL) and weak borrowers (the one with worse credit history), as identified by the positive coefficient on $N P L^{*} B Q$. For the influence of non-performing loans on bank lending decisions, see Altavilla et al. (2019).
} 
definitions of the variable "Large" (in two different subsamples), based on a total of 20 different regressions. That is, each number corresponds to an estimated coefficient in a different regression with a different measure of large bank; moreover, results in the first two columns are obtained using the entire sample whereas those in the last two columns use a restricted sample including only the same number of centrally and locally supervised banks.

The coefficient of interest does not change substantially for alternative definitions of very large banks in absolute terms, implying that the results in Table 7 are not driven by the exact definition used to identify very large banks. ${ }^{13}$ However, results are strikingly different when we focus on the largest bank in each country, as all the coefficients for the variable "Largest bank in country" are very small and not statistically significant.

\section{[Insert Table 8 here]}

Overall, results in Table 7 and 8 provide information on the relative importance of the two competing mechanisms outlined above. The estimates show that there is limited support for the incentive hypothesis since the centralisation of banking supervision does not increase the risk sensitivity of credit supply for weaker banks (as proxied by higher NPL ratios), or a continuous measure of bank size, or for banks that are particularly systemic for the local but not necessarily for the central supervisor (largest bank in each country). At the same time, the results provide support for the capacity hypothesis, since the reduction in risk taking due to centralised bank supervision is particularly significant for the very large banks, most notably in stressed countries (banks larger than 300, 400, 500 billion or beyond). This provides further support for the hypothesis of a non-linearity in the resources required to supervise banks with different sizes, whereby centralised supervisors with broader and better human resources would be more effective in reducing the risk-taking of very large banks, which tend to be more sophisticated, involved in more complex activities and also with a stronger cross-border presence. Overall, and more generally, the mechanism driving the results is more consistent with broader and better human resources available to the supranational supervisor (human capital accumulation, e.g. Gennaioli, LaPorta, Lopez-de-Silanes and Shleifer, 2013) rather than with different incentives between local supervisors and the new supranational institution (e.g. King and Levine, 1993; Hall and Jones, 1999; and Acemoglu, Johnson, and Robinson, 2001 and 2005).

\subsection{Banking supervision and monetary policy interactions}

In this subsection we analyse how banking supervision interacts with monetary policy in affecting bank risk-taking and loan supply. In particular, the question we address is whether banks shift their

\footnotetext{
${ }^{13}$ Results are not robust for total assets higher than 200, but they are robust for higher than 300,400 or other thresholds above 500 billion euros. For the results on non-stressed countries, see Table A.2.
} 
credit supply to ex-ante riskier borrowers following periods of monetary policy accommodation, and how these effects interact with different institutional designs of banking supervision. ${ }^{14}$

Measuring the effects of monetary policy shocks in an environment where the central bank has announced and implemented both conventional and unconventional policies poses special challenges. This is because we cannot rely on a single interest rate to proxy the amount of policy accommodation provided by the monetary authority. In fact, as shown in Altavilla et al. (2019), while conventional monetary policy moves the front end of the yield curve, unconventional measures might exert a larger impact on longer maturities.

Therefore, to fully capture the amount of policy accommodation provided by the central bank we proceed as follows. We construct a variable, $\operatorname{Shock}^{M P}$, that measures the principal component of all monetary policy surprises from high-frequency intraday data on risk-free (overnight index swap, OIS) rates with different maturities, ranging from 1 month to 10 years. These surprises are calculated by measuring changes in risk free rates in a narrow time window around official monetary policy communications. ${ }^{15}$ More precisely, for each Governing Council meeting, we first measure the realised policy surprise as the principal component of interest rate changes from 15 minutes before the press release to 15 minutes after the press conference, and then we cumulate them to match the frequency of the credit registers.

Figure 3 shows the indicator of policy surprises obtained, where positive (negative) numbers indicate a monetary policy tightening (easing). Although the measure fluctuates around zero, events associated with important policy announcement are clearly visible: the introduction of forward guidance in July 2013, the introduction of negative rates in June 2014, the allotment of the first targeted longer-term refinancing operations (TLTRO) in September 2014 and the announcement of the expanded asset purchase programme (APP) in January 2015 are all instances where the negative values of the surprise indicator correctly point to events associate with substantial monetary policy accommodation.

\section{[Insert Figure 3 here]}

We use this variable to study whether monetary policy easing has an amplification effect on the risk-taking behaviour of European banks, and whether centralised banking supervision affects this relationship. The model specification takes the following form:

\footnotetext{
${ }^{14}$ For the risk-taking channel of monetary policy, see Adrian and Shin (2010); also Jiménez, Ongena, Peydró and Saurina (2014), and the references therein. For monetary policy rates and bank risk-taking, see also Diamond and Rajan (2012). For the bank lending channel, see Kashyap and Stein (2000).

${ }^{15}$ The surprises are from the Euro Area Monetary Policy Event-Study Database (EA-MPD) developed by Altavilla et al. (2019).
} 


$$
\begin{aligned}
\operatorname{Loans}_{b, s, f, t}= & \alpha^{F E}+\delta B Q_{f, t-1}+\theta \operatorname{Sup}_{b, t-1}+\lambda\left(B Q_{f, t-1} \times \operatorname{Sup}_{b, t-1}\right)+\mu \operatorname{Shock}_{t-1}^{M P} \\
& +\psi\left(\operatorname{Shock}_{t-1}^{M P} \times B Q_{f, t-1}\right)+\phi\left(\operatorname{Shock}_{t-1}^{M P} \times \operatorname{Sup}_{b, t-1}\right) \\
& +\eta\left(\operatorname{Shock}_{t-1}^{M P} \times B Q_{f, t-1} \times \operatorname{Sup}_{b, t-1}\right)+\Omega X_{b, f, t-1}+\epsilon_{b, s, f, t}
\end{aligned}
$$

Where $X_{b, f, t-1}$ includes all remaining double and triple interactions. The above model can be used to test whether monetary policy easing increases credit supply towards riskier firms $(\psi<0)$ and whether centralised supervision offset this effect $(\eta>0)$. In other words, monetary accommodation might lead to a relative increase in risk-taking that can however be mitigated or fully offset by centralised supervision. Finally, we assess whether the relationship between risk-taking and the monetary policy stance differs across banks, analogously to that between risk-taking and centralised supervision. Table 9 reports the results for the different specifications varying according to the set of fixed effects introduced in the model as done in the previous tables. The first two rows of the table confirm the two main results obtained in Table 3. First, in both stressed and non-stressed countries credit supply is sensitive to borrower credit risk $(\delta<0)$. Second, centralised supervision increases this sensitivity, especially in stressed countries $(\lambda<0)$. Moreover, the results also show that, following monetary policy easing, banks increase their loan supply towards firms with very high exante credit risk $(\psi<0)$. This result is in line with the presence of a risk-taking channel of monetary policy. Moreover, this effect is offset by centralised supervision $(\eta>0)$, an important finding which confirms that while monetary policy and supervision have independent objectives, there are important interactions whereby the two policies can either conflict or complement each other. Our previous results, indicating that centralised supervision curtails risk taking associated to loan ever-greening without compromising lending towards more productive firms, suggest that the two policies do not conflict but rather complement each other. ${ }^{16}$

\section{[Insert Table 9 here]}

The final exercise is motivated by our previous finding that centralised banking supervision influences the risk sensitivity of bank credit supply essentially by relaxing capacity constraints of local supervisors (capacity hypothesis). We augment the model in equation 4 in order to investigate if also the interaction between bank supervision and monetary policy is different for Large banks. Results are reported in Table 10.

\section{[Insert Table 10 here]}

Although differing in terms of size of the estimated coefficients, the results for stressed and nonstressed countries appear to be qualitatively similar. As above, independently of where a bank operates, monetary policy easing tends to increase risk-taking, as banks supply more credit to very

\footnotetext{
${ }^{16}$ The results on the interaction between supervision and productivity are shown in Table 4 . These are confirmed when augmenting the model with monetary policy measures (results not shown).
} 
risky borrowers, and centralised banking supervision compresses this monetary policy induced risktaking. The introduction of the non-linear term for bank size plays a significant role and sheds further light on the heterogeneous transmission of monetary policy across banks. Also for this set of banks centralised supervision tends to compress the credit supply originated toward very risky borrowers, i.e. $\left(\operatorname{Large}_{b} \times B Q_{f, t-1} \times \operatorname{Sup}_{b, t-1}\right)<0$. Importantly, while the risk-taking channel of monetary policy is stronger for largest banks $\left(\operatorname{Large}_{b} \times B Q_{f, t-1} \times \operatorname{Shock}_{t-1}^{M P}\right)<0$, centralised supervision is again able to compress this (excessive) risk-taking, $\left(\operatorname{Large}_{b} \times B Q_{f, t-1} \times \operatorname{Shock}_{t-1}^{M P} \times \operatorname{Sup}_{b, t-1}\right)>0$, thereby confirming the role of prudential supervision in complementing monetary policy in particular for the very large banks which, as discussed above, is due to the fact that their complexity requires broader resources for an effective supervision.

\section{Conclusions}

The financial crisis highlighted the limitations of the prevailing supervisory framework in preventing excessive risk-taking and ensuring the resilience of the banking system to large adverse shocks. This fostered a debate on changes to the institutional setting, including the potential benefits of supranational supervision.

In this paper we analyse the impact of banking supervision on credit supply and risk-taking, and its interactions with monetary policy. Using a unique granular dataset comprising multiple European credit registers, both for euro area and non-euro area EU countries, we establish two main results.

First, supranational banking supervision influences credit supply by reducing bank excessive risktaking. In more detail, banks that are supervised at the supranational level compress credit supply to borrowers with very high ex-ante and ex-post credit risk (proxied by loan delinquency), while raising credit supply to stronger firms. Effects are stronger for banks operating in financially stressed countries. Moreover, exploiting heterogeneity across banks, we conclude that the mechanism underlying the results is connected to higher quantity and quality of human resources available to the supranational supervisor and not to changes in incentives due to the institutional change.

Second, prudential supervision and monetary policy display important complementarities. Exploiting a new dataset of high-frequency monetary policy surprises - measuring the impact on different segments of the term structure of risk-free rates around official European Central Bank policy decisions - we show that despite the evidence of an active risk-taking channel of monetary policy, centralised banking supervision offsets the excessive bank risk-taking induced by accommodative monetary policy stance (but not the more productive risk-taking).

Beyond supervision, we show two results which are more general for economics. First, the benefits of a new institution stem from human capital accumulation (broader and better human 
resources) rather than from different incentives between the local institutions and the new supranational institution. Second, we show that using multiple credit registers (first time in the literature) is crucial for external validity. For instance, results are stronger for those countries more affected by the euro area crisis, suggesting that while the evidence based on a single credit register can identify credit supply and risk-taking (internal validity), a broader view is required to ensure external validity, which is crucial not only for testing academic theories, but for policy analysis. 


\section{References}

Acemoglu, D., Johnson, S., and Robinson, J. A. (2001). The colonial origins of comparative development: An empirical investigation. American Economic Review, 91(5), 1369-1401.

Acemoglu, D., Johnson, S., and Robinson, J. A. (2005). Institutions as a fundamental cause of long-run growth. Handbook of economic growth, 1, 385-472.

Acemoglu, D., and Robinson, J. A. (2013). Economics versus politics: Pitfalls of policy advice. Journal of Economic Perspectives, 27(2), 173-92.

Adrian, T., and Shin, H. S. (2010). Financial intermediaries and monetary economics. In Handbook of monetary economics (Vol. 3, pp. 601-650). Elsevier.

Agarwal, S., Lucca, D., Seru, A., and Trebbi, F. (2014). Inconsistent regulators: Evidence from banking. Quarterly Journal of Economics, 129(2), 889-938.

Akerlof, G. A. (1982). Labor Contracts as Partial Gift Exchange. Quarterly Journal of Economics, 97, 543-569.

Akerlof, G. A., Romer, P. M., Hall, R. E., and Mankiw, N. G. (1993). Looting: the economic underworld of bankruptcy for profit. Brookings Papers on Economic Activity, 1993(2), 1-73.

Altavilla, C., Boucinha, M., Peydró, J. L., Smets, C. (2019). Non-performing loans and bank credit supply: evidence from European credit registers. Mimeo.

Altavilla, C., Brugnolini, L., Gürkaynak, R. S., Motto, R., and Ragusa, G. (2019). Measuring Euro Area Monetary Policy. Journal of Monetary Economics, vol.108, 162-179.

Amiti, M., and Weinstein, D. E. (2011). Exports and financial shocks. Quarterly Journal of Economics, 126(4), 1841-1877.

Beck, T., Todorov, R., and Wagner, W. (2013). Supervising cross-border banks: theory, evidence and policy. Economic Policy, 28(73), 5-44.

Bernanke, B. S., and Blinder, A. S. (1988). Credit, money, and aggregate demand. American Economic Review, vol. 78(2), 435-439.

Bernanke, B., and Blinder, A. (1992). The Federal Funds Rate and the Channels of Monetary Transmission". American Economic Review, 82 (4): 901-921.

Bonfim, D., Cerqueiro, G., Degryse, H., \& Ongena, S. (2019). Inspect what you expect to get respect: can bank supervisors kill zombie lending. Mimeo.

Caballero, R. J., Hoshi, T., and Kashyap, A. K. (2008). Zombie lending and depressed restructuring in Japan. American Economic Review, 98(5), 1943-77. 
Calzolari, G., Colliard, J. E., and Loranth, G. (2018). Multinational banks and supranational supervision. Review of Financial Studies, 32(8), 2997-3035.

Carletti, E., Dell'Ariccia, G., and Marquez, R. (2016). Supervisory Incentives in a Banking Union. IMF Working Paper No. WP/16/186.

Constancio, V. (2013). Establishment of the Single Supervisory Mechanism; the first pillar of the Banking Union. Speech at 11th Annual European Financial Services Conference, Brussels.

Dal Bó, E., Finan, F., and Rossi, M. A. (2013). Strengthening state capabilities: The role of financial incentives in the call to public service. Quarterly Journal of Economics, 128(3), 1169-1218.

Dell'Ariccia, G., and Marquez, R. (2006). Competition among regulators and credit market integration. Journal of Financial Economics, 79(2), 401-430.

Dell'Ariccia, G., Laeven, L., and Suarez, G. A. (2017). Bank leverage and monetary policy's risktaking channel: evidence from the United States. Journal of Finance, 72(2), 613-654.

Dewatripont, M., and Maskin, E. (1995). Credit and efficiency in centralized and decentralized economies. Review of Economic Studies, 62(4), 541-555.

Dewatripont, M., and Tirole, J. (1994). The prudential regulation of banks. ULB-Universite Libre de Bruxelles.

Dewatripont, M., and Freixas, X. (2012). The crisis aftermath: New regulatory paradigms. Centre for Economic Policy Research.

Diamond, D. W., and Rajan, R. G. (2012). Illiquid banks, financial stability, and interest rate policy. Journal of Political Economy, 120(3), 552-591.

Draghi M. (2018). The Benefits of European Supervision. Speech by the President of the ECB, at the ACPR Conference on Financial Supervision, Paris, 18 September 2018.

Drechsler, I., Savov, A., and Schnabl, P. (2017). The deposits channel of monetary policy. Quarterly Journal of Economics, 132(4), 1819-1876.

Eisenbach, T. M., Lucca, D. O., and Townsend, R. M. (2016). The economics of bank supervision. NBER Working Paper No. w22201.

Eisenbach, T. M., Haughwout, A., Hirtle, B., Kovner, A., Lucca, D. O., and Plosser, M. C. (2017). Supervising large, complex financial institutions: What do supervisors do?. Economic Policy Review, (23-1), 57-77.

Freixas, X., Laeven, L., and Peydró, J. L. (2015). Systemic risk, crises, and macroprudential regulation. MIT Press.

Freixas, X., and Rochet, J. C. (2008). Microeconomics of banking. MIT press. 
Gai, P., Kemp, M., Serrano, A. S., and Schnabel, I. (2019). Regulatory complexity and the quest for robust regulation. Reports of the Advisory Scientific Committee, (8).

Gennaioli, N., La Porta, R., Lopez-de-Silanes, F., and Shleifer, A. (2013). Human capital and regional development. Quarterly Journal of Economics, 128(1), 105-164.

Granja, J., and Leuz, C. (2017). The death of a regulator: Strict supervision, bank lending and business activity. NBER Working Paper No. 24168

Hakenes, H., and Schnabel, I., (2014). Regulatory Capture by Sophistication. CEPR Discussion Paper No. DP10100.

Hall, R. E., and Jones, C. I. (1999). Why do some countries produce so much more output per worker than others?. Quarterly Journal of Economics, 114(1), 83-116.

Hayek, F. A. (1945). The use of knowledge in society. American Economic Review, 35(4):519530.

Hirtle, B., Kovner, A., and Plosser, M. C. (2018). The impact of supervision on bank performance. FRB of NY Staff Report No. 768.

Igan, D., and Lambert, T. (2019). Bank Lobbying: Regulatory Capture and Beyond. IMF Working Paper No. WP/19/171.

Jiménez, G., Ongena, S., Peydró, J. L., and Saurina, J. (2012). Credit supply and monetary policy: Identifying the bank balance-sheet channel with loan applications. American Economic Review, 102(5), 2301-26.

Jiménez, G., Ongena, S., Peydró, J. L., and Saurina, J. (2014). Hazardous times for monetary policy: What do twenty-three million bank loans say about the effects of monetary policy on credit risk-taking?. Econometrica, 82(2), 463-505.

Kandrac, J., and Schlusche, B. (2019). The effect of bank supervision on risk taking: Evidence from a natural experiment. FEDS Working Paper No. 2017-079

Kane, E. J. (1989). The S \& L insurance mess: How did it happen?. The Urban Institute.

Kashyap, A. K., and Stein, J. C. (2000). What do a million observations on banks say about the transmission of monetary policy?. American Economic Review, 90(3), 407-428.

Khwaja, A. I., and Mian, A. (2008). Tracing the impact of bank liquidity shocks: Evidence from an emerging market. American Economic Review, 98(4), 1413-42.

King, R. G., and Levine, R. (1993). Finance and growth: Schumpeter might be right. Quarterly Journal of Economics, 108(3), 717-737. 
Johnson, S., and Kwak, J. (2010). 13 Bankers: The Wall Street Takeover and the Next Financial Meltdown, Pantheon Books.

Laffont, J. J. (1999). Political economy, information and incentives. European Economic Review, 43(4-6), 649-669.

Laffont, J. J., and Tirole, J. (1991). The politics of government decision-making: A theory of regulatory capture. Quarterly Journal of Economics, 106(4), 1089-1127.

Laffont, J. J., and Tirole, J. (1993). A theory of incentives in procurement and regulation. MIT press.

Laffont, J. J., and Martimort, D. (1999). Separation of regulators against collusive behavior. Rand Journal of Economics, 232-262.

Martynova, N., Perotti, E. C., and Suarez, J. (2019). Bank capital forbearance. Available at SSRN 3354512.

Mian, A. (2006). Distance constraints: The limits of foreign lending in poor economies. Journal of Finance, 61(3), 1465-1505.

Mishkin, F. S. (2001). The transmission mechanism and the role of asset prices in monetary policy. NBER Working Paper No. w8617.

Morgan, D. P. (2002). Rating banks: Risk and uncertainty in an opaque industry. American Economic Review, 92(4), 874-888.

Myers, S. C., and Rajan, R. G. (1998). The paradox of liquidity. Quarterly Journal of Economics, 113(3), 733-771.

Paravisini, D. (2008). Local bank financial constraints and firm access to external finance. The Journal of Finance, 63(5), 2161-2193.

Rajan, R. G. (1994). Why bank credit policies fluctuate: A theory and some evidence. Quarterly Journal of Economics, 109(2), 399-441.

Repullo, R. (2017). Hierarchical bank supervision. CEPR Discussion Paper No. DP12475.

Rochet, J. C. (2009). Why are there so many banking crises?: the politics and policy of bank regulation. Princeton University Press.

Romer, C. D., and Romer, D. H. (2000). Federal Reserve information and the behavior of interest rates. American Economic Review, 90(3), 429-457.

Rostagno M., Altavilla C., Carboni G., Lemke W., Motto R., Saint-Guilhem A. and Yiangou, J., (2019). A Tale of two Decades: The ECB’s Monetary Policy at 20. ECB Working Paper. 
Schnabl, P. (2012). The international transmission of bank liquidity shocks: Evidence from an emerging market. Journal of Finance, 67(3), 897-932.

Shapiro, C. and Stiglitz, J. (1984). Equilibrium Unemployment as a Worker Discipline Device. American Economic Review, 74(3), 433-444.

Stigler, G. J. (1971). The theory of economic regulation. Bell Journal of Economics and Management Science, 3-21.

Tirole, J. (2014). Market power and regulation. Scientific Background on the Sveriges Riksbank Prize in Economic Sciences in Memory of Alfred Nobel, 1-6.

Weiss, A. (1980). Job queues and layoffs in labor markets with flexible wages. Journal of Political economy, 88(3), 526-538. 
Table 1: Sample composition

\begin{tabular}{lrcccc}
\hline & $\begin{array}{c}\text { Reporting } \\
\text { Threshold }\end{array}$ & $\begin{array}{c}\text { Initial Sample } \\
\text { (in million) }\end{array}$ & $\begin{array}{c}\text { \# of banks } \\
\text { Original Sample }\end{array}$ & $\begin{array}{c}\text { Final Sample } \\
\text { (in million) }\end{array}$ & $\begin{array}{c}\text { \# of banks } \\
\text { Final Sample }\end{array}$ \\
\hline \hline Austria & 350,000 & 1.4 & 1601 & 0.5 & 65 \\
Belgium & 0 & 13.3 & 144 & 6.2 & 36 \\
Germany & $1,000,000$ & 11.1 & 1828 & 4.7 & 498 \\
Spain & 6,000 & 23.6 & 283 & 16.7 & 133 \\
France & 25,000 & 37.7 & 522 & 24.8 & 295 \\
Ireland & 500 & 4.3 & 4 & - & - \\
Italy & 30,000 & 148.2 & 1576 & 28.2 & 731 \\
Lithuania & 290 & 0.3 & 166 & 0.3 & 11 \\
Latvia & 0 & 12.7 & 109 & - & - \\
Malta & 5,000 & 0.1 & 26 & - & 107 \\
Portugal & 50 & 8.8 & 198 & 6.2 & - \\
Slovenia & 0 & 0.2 & 26 & - & 11 \\
Slovakia & 0 & 0.9 & 30 & 2 & 52 \\
Romania & 4,440 & 20.2 & 96 & 1.5 & 18 \\
Czech Republic & 0 & 4.8 & 41 & & \\
\hline
\end{tabular}

Note: The table reports for each country the reporting threshold of the individual credit register, the initial number of observation available in the dataset and the final number of observation obtained after cleaning and harmonising the data, as well as collapsing the data at the lender-borrower-time period. 
Table 2: Descriptive statistics

\begin{tabular}{|c|c|c|c|c|c|c|}
\hline & \multicolumn{3}{|c|}{ Stressed Countries } & \multicolumn{3}{|c|}{ Non-Stressed Countries } \\
\hline & Mean & St.Dev. & \# obs. & Mean & St.Dev. & \# obs. \\
\hline Loan volume (Loans) & 516 & 12,078 & $48,507,843$ & 1,716 & 15,649 & $8,526,222$ \\
\hline Borrower Quality (BQ) & 0.05 & 0.19 & $45,828,620$ & 0.03 & 0.16 & $7,396,700$ \\
\hline Centralised Supervision (Sup) & 0.34 & 0.47 & $48,507,843$ & 0.50 & 0.50 & $8,526,222$ \\
\hline Monetary Policy Shock (Shock ${ }^{\mathrm{MP}}$ ) & -1.04 & 4.22 & $48,507,843$ & -1.15 & 4.25 & $8,526,222$ \\
\hline NPL ratio (NPL) & 0.20 & 0.10 & $48,507,843$ & 0.05 & 0.04 & $8,526,222$ \\
\hline Size & 5.35 & 6.22 & $48,507,691$ & 15.13 & 11.41 & $8,526,194$ \\
\hline Large & 0.16 & 0.36 & $48,507,843$ & 0.07 & 0.26 & $8,526,222$ \\
\hline Productivity (Prod) & 217.7 & 183.9 & $40,171,006$ & 240.69 & 173.54 & $6,496,651$ \\
\hline
\end{tabular}

Note: The table reports the descriptive statistics for the main variables used in the empirical analysis. The abbreviations used in equations and regression tables are shown in parenthesis. Loan volume is the total amount of drawn and undrawn credit at the bank-borrower-time level in thousands of euros. Borrower quality indicates, for each borrower, the ratio between exposures in arrears and total exposures. Centralised supervision is a dummy variable that takes value one for banks supervised at supranational level (i.e. directly by the ECB) after November 2014. Monetary policy shock is the first principal component of the monetary policy surprises extracted from the high-frequency intraday yields at different maturities during all dates of policy announcements covered in the sample. Productivity is defined as the ratio between labour productivity (measured as the ratio of value added over number of employees) and average personnel costs at the countrysector-time level. Size is the market share of the bank in each sector in each period. Large is a dummy variable that takes value 1 if the total assets of the bank are larger than Euro 500bn. The NPL ratio measures for each bank and time period the share of non-performing exposure to total exposure. 
Table 3: Banking supervision and risk-taking

\begin{tabular}{|c|c|c|c|c|c|c|c|c|}
\hline & \multicolumn{4}{|c|}{ Stressed Countries } & \multicolumn{4}{|c|}{ Non-Stressed Countries } \\
\hline & \multicolumn{2}{|c|}{$i=-1$} & \multicolumn{2}{|c|}{$i=1$} & \multicolumn{2}{|c|}{$i=-1$} & \multicolumn{2}{|c|}{$i=1$} \\
\hline & (1) & $(2)$ & (3) & (4) & (5) & (6) & (7) & (8) \\
\hline $\mathrm{BQ}_{\mathrm{f}, \mathrm{t}+\mathrm{i}}$ & $\begin{array}{l}-0.246^{*} \\
(0.0245)\end{array}$ & - & $\begin{array}{c}-0.135^{* * *} \\
(0.0488)\end{array}$ & - & $\begin{array}{c}-0.185^{* * *} \\
(0.0424)\end{array}$ & - & $\begin{array}{l}-0.0510^{*} \\
(0.0278)\end{array}$ & \\
\hline $\mathrm{BQ}_{\mathrm{f}, \mathrm{t}+\mathrm{i}} \times \operatorname{Sup}_{\mathrm{b}, \mathrm{t}-1}$ & $\begin{array}{c}-0.434 * * * \\
(0.0666)\end{array}$ & $\begin{array}{c}-0.268^{* * *} \\
(0.0954)\end{array}$ & $\begin{array}{c}-0.440^{* * *} \\
(0.0598)\end{array}$ & $\begin{array}{l}-0.200 * * \\
(0.0872)\end{array}$ & $\begin{array}{c}-0.363^{* * *} \\
(0.108)\end{array}$ & $\begin{array}{l}-0.0450 \\
(0.0980)\end{array}$ & $\begin{array}{c}-0.255^{* * *} \\
(0.0571)\end{array}$ & $\begin{array}{c}0.101 \\
(0.0937)\end{array}$ \\
\hline $\mathrm{N}$ & $40,626,537$ & $30,703,723$ & $41,181,446$ & $31,393,573$ & $6,879,163$ & $3,672,419$ & $6,866,876$ & $3,672,058$ \\
\hline R-squared & 0.704 & 0.771 & 0.707 & 0.772 & 0.815 & 0.845 & 0.826 & 0.846 \\
\hline \multicolumn{9}{|l|}{ Fixed effects } \\
\hline Bank*Firm & Y & Y & $\mathrm{Y}$ & $\mathrm{Y}$ & $\mathrm{Y}$ & $\mathrm{Y}$ & $\mathrm{Y}$ & $\mathrm{Y}$ \\
\hline Firm*Time & $\mathrm{N}$ & $\mathrm{Y}$ & $\mathrm{N}$ & $\mathrm{Y}$ & $\mathrm{N}$ & $\mathrm{Y}$ & $\mathrm{N}$ & $\mathrm{Y}$ \\
\hline Sector*Time & $\mathrm{Y}$ & - & $\mathrm{Y}$ & - & $\mathrm{Y}$ & - & $\mathrm{Y}$ & - \\
\hline Bank*Time & $\mathrm{Y}$ & $\mathrm{Y}$ & Y & Y & $\mathrm{Y}$ & $\mathrm{Y}$ & Y & $\mathrm{Y}$ \\
\hline
\end{tabular}

Note: The dependent variable is the (log-)credit granted (drawn and undrawn) by bank "b" to firm " $\mathrm{f}$ " operating in sector " $\mathrm{s"}$ " at time " $\mathrm{t}$ ". BQ (Borrower quality) indicates, for each borrower, the ratio between exposures in arrears and total exposures. Sup (Centralised supervision) is a dummy variable that takes value one for banks supervised at supranational level (i.e. directly by the ECB) after November 2014. Data are at semi-annual for the period 2012H1 - 2017H2. "-" implies that the fixed effects are spanned by other effects, while "Y" and "N" imply that those fixed effects are included, and not included, respectively. Standard errors clustered at bank level in parentheses: ${ }^{*} \mathrm{p}<0.1,{ }^{* *} \mathrm{p}<0.05$, ${ }^{* * *} \mathrm{p}<0.01$. 
Table 4: Bank supervision and productivity

\begin{tabular}{|c|c|c|c|c|c|c|c|c|}
\hline & \multicolumn{4}{|c|}{ Stressed countries } & \multicolumn{4}{|c|}{ Non-Stressed Countries } \\
\hline & \multicolumn{2}{|c|}{$i=-1$} & \multicolumn{2}{|c|}{$\mathrm{i}=1$} & \multicolumn{2}{|c|}{$i=-1$} & \multicolumn{2}{|c|}{$i=1$} \\
\hline & $(1)$ & $(2)$ & (3) & (4) & (5) & $(6)$ & $(7)$ & (8) \\
\hline $\mathrm{BQ}_{\mathrm{f}, \mathrm{t}+\mathrm{i}}$ & $\begin{array}{l}-0.0756^{*} \\
(0.0401)\end{array}$ & & $\begin{array}{c}-0.174 * * * \\
(0.0557)\end{array}$ & & $\begin{array}{c}-0.146 * * * \\
(0.0443)\end{array}$ & & $\begin{array}{l}-0.0563 * \\
(0.0253)\end{array}$ & \\
\hline $\mathrm{BQ}_{\mathrm{f}, \mathrm{t}+\mathrm{i}} \times \operatorname{Sup}_{\mathrm{b}, \mathrm{t}+1}$ & $\begin{array}{c}-0.429 * * * \\
(0.0659)\end{array}$ & $\begin{array}{c}-0.285^{* * *} \\
(0.0942)\end{array}$ & $\begin{array}{c}-0.448^{* * *} \\
(0.0651)\end{array}$ & $\begin{array}{l}-0.202^{* *} \\
(0.0899)\end{array}$ & $\begin{array}{c}-0.394 * * * \\
(0.112)\end{array}$ & $\begin{array}{c}-0.00276 \\
(0.120)\end{array}$ & $\begin{array}{c}-0.256^{* * *} \\
(0.0513)\end{array}$ & $\begin{array}{c}0.0386 \\
(0.0972)\end{array}$ \\
\hline $\operatorname{Prod}_{\mathrm{s}, \mathrm{t}+\mathrm{i}}$ & $\begin{array}{c}-0.213 * * * \\
(0.0408)\end{array}$ & & $\begin{array}{c}-0.251 * * * \\
(0.0445)\end{array}$ & & $\begin{array}{c}0.349 * * * \\
(0.104)\end{array}$ & & $\begin{array}{c}-0.100 \\
(0.0994)\end{array}$ & \\
\hline $\mathrm{BQ}_{\mathrm{f}, \mathrm{t}+\mathrm{i}} \times \operatorname{Prod}_{\mathrm{s}, \mathrm{t}+\mathrm{i}}$ & $\begin{array}{c}0.288^{* * *} \\
(0.0812)\end{array}$ & & $\begin{array}{c}0.0995^{* *} \\
(0.0414)\end{array}$ & & $\begin{array}{c}0.246^{* *} \\
(0.107)\end{array}$ & & $\begin{array}{c}0.399 * * * \\
(0.0812)\end{array}$ & \\
\hline $\operatorname{Prod}_{\mathrm{s}, \mathrm{t}+\mathrm{i}} \times \operatorname{Sup}_{\mathrm{b}, \mathrm{t}-1}$ & $\begin{array}{c}0.0426 \\
(0.0383)\end{array}$ & $\begin{array}{l}-0.0115 \\
(0.0351)\end{array}$ & $\begin{array}{c}0.0546 \\
(0.0381)\end{array}$ & $\begin{array}{c}0.0113 \\
(0.0392)\end{array}$ & $\begin{array}{l}-0.0220 \\
(0.0635)\end{array}$ & $\begin{array}{c}0.176 \\
(0.140)\end{array}$ & $\begin{array}{l}0.116^{* *} \\
(0.0580)\end{array}$ & $\begin{array}{c}0.189 \\
(0.151)\end{array}$ \\
\hline $\begin{array}{l}\mathrm{N} \\
\mathrm{R} \text {-squared }\end{array}$ & $\begin{array}{c}37,753,379 \\
0.714\end{array}$ & $\begin{array}{c}28,374,474 \\
0.779\end{array}$ & $\begin{array}{c}32,123,122 \\
0.728\end{array}$ & $\begin{array}{c}24,285,787 \\
0.789 \\
\end{array}$ & $\begin{array}{l}5,750,158 \\
0.835\end{array}$ & $\begin{array}{l}2,713,259 \\
0.867\end{array}$ & $\begin{array}{c}4,676,219 \\
0.855 \\
\end{array}$ & $\begin{array}{c}2,182,565 \\
0.873 \\
\end{array}$ \\
\hline Fixed effects & & & & & & & & \\
\hline Bank*Firm & $\mathrm{Y}$ & $\mathrm{Y}$ & $\mathrm{Y}$ & $\mathrm{Y}$ & $\mathrm{Y}$ & $\mathrm{Y}$ & $\mathrm{Y}$ & $\mathrm{Y}$ \\
\hline Firm*'Time & $\mathrm{N}$ & $\mathrm{Y}$ & $\mathrm{N}$ & $\mathrm{Y}$ & $\mathrm{N}$ & Y & $\mathrm{N}$ & $\mathrm{Y}$ \\
\hline Sector*'Time & $\mathrm{Y}$ & - & $\mathrm{Y}$ & - & $\mathrm{Y}$ & - & $\mathrm{Y}$ & - \\
\hline Bank*Time & $\mathrm{Y}$ & $\mathrm{Y}$ & $\mathrm{Y}$ & $\mathrm{Y}$ & $\mathrm{Y}$ & $\mathrm{Y}$ & $\mathrm{Y}$ & $\mathrm{Y}$ \\
\hline
\end{tabular}

Note: The dependent variable is the (log-)credit granted (drawn and undrawn) by bank "b" to firm "f" operating in sector "s" at time "t". BQ (borrower quality) indicates, for each borrower, the ratio between exposures in arrears and total exposures. Sup (centralised supervision) is a dummy variable that takes value one for banks supervised at supranational level (i.e. directly by the ECB) after November 2014. Prod (productivity) is defined as the ratio between labour productivity (measured as the ratio of value added over number of employees) and average personnel costs at the country-sector-time level. Data are at semi-annual for the period 2012H1 2017H2. "-” implies that the fixed effects are spanned by other effects, while "Y" and "N" imply that those fixed effects are included, and not included, respectively. Standard errors clustered at bank level in parentheses: * $\mathrm{p}<0.1, * * \mathrm{p}<0.05, * * * \mathrm{p}<0.01$. 
Table 5: Robustness: Credit drawn

\begin{tabular}{|c|c|c|c|c|}
\hline & \multicolumn{2}{|c|}{ Stressed Countries } & \multicolumn{2}{|c|}{ Non-Stressed Countries } \\
\hline & $\begin{array}{c}\mathrm{i}=-1 \\
(1)\end{array}$ & $\begin{array}{c}\mathrm{i}=1 \\
(2)\end{array}$ & $\begin{array}{c}i=-1 \\
(3)\end{array}$ & $\begin{array}{c}i=1 \\
(4)\end{array}$ \\
\hline $\mathrm{BQ}_{\mathrm{f}, \mathrm{t}-1} \times \operatorname{Sup}_{\mathrm{b}, \mathrm{t}-1}$ & $\begin{array}{c}-0.230 * * * \\
(0.0706)\end{array}$ & $\begin{array}{c}-0.241 * * * \\
(0.0830)\end{array}$ & $\begin{array}{l}-0.0658 \\
(0.0569)\end{array}$ & $\begin{array}{l}0.00577 \\
(0.0532)\end{array}$ \\
\hline $\mathrm{N}$ & $25,407,607$ & $26,098,126$ & $2,945,492$ & $2,929,344$ \\
\hline R-squared & 0.900 & 0.900 & 0.940 & 0.942 \\
\hline \multicolumn{5}{|l|}{ Fixed effects } \\
\hline Bank*Firm & $\mathrm{Y}$ & $\mathrm{Y}$ & $\mathrm{Y}$ & $\mathrm{Y}$ \\
\hline Firm*Time & $\mathrm{Y}$ & $\mathrm{Y}$ & $\mathrm{Y}$ & $\mathrm{Y}$ \\
\hline Bank*Time & $\mathrm{Y}$ & $\mathrm{Y}$ & $\mathrm{Y}$ & $\mathrm{Y}$ \\
\hline
\end{tabular}

Note: The dependent variable is the (log-)credit drawn by bank "b" to firm "f" operating in sector "s" at time "t". BQ (Borrower quality) indicates, for each borrower, the ratio between exposures in arrears and total exposures. Sup (Centralised supervision) is a dummy variable that takes value one for banks supervised at supranational level (i.e. directly by the ECB) after November 2014. Data are at semi-annual for the period 2012H1 - 2017H2. Standard errors clustered at bank level in parentheses: ${ }^{*} \mathrm{p}<0.1,{ }^{* *} \mathrm{p}<0.05,{ }^{* * *} \mathrm{p}<0.01$. 
Table 6: Robustness: restricted sample for euro area banks (6 banks per country) and placebo test based on non-euro area countries and banks

\begin{tabular}{|c|c|c|c|c|c|c|}
\hline & \multicolumn{2}{|c|}{ Stressed Countries } & \multicolumn{2}{|c|}{ Non-Stressed Countries } & \multicolumn{2}{|c|}{ EU non EA } \\
\hline & $\begin{array}{c}\mathrm{i}=-1 \\
(1)\end{array}$ & $\begin{array}{c}\mathrm{i}=1 \\
(2)\end{array}$ & $\begin{array}{c}\mathrm{i}=-1 \\
(3)\end{array}$ & $\begin{array}{c}i=1 \\
(4)\end{array}$ & $\begin{array}{c}\mathrm{i}=-1 \\
(5)\end{array}$ & $\begin{array}{c}i=1 \\
(6)\end{array}$ \\
\hline $\mathrm{BQ}_{\mathrm{f}, \mathrm{t}+\mathrm{i}} \times \operatorname{Sup}_{\mathrm{b}, \mathrm{t}-1}$ & $\begin{array}{c}-0.338^{* *} \\
(0.155)\end{array}$ & $\begin{array}{c}-0.167^{*} \\
(0.088)\end{array}$ & $\begin{array}{c}-0.000281 \\
(0.194)\end{array}$ & $\begin{array}{c}-0.0618 \\
(0.151)\end{array}$ & $\begin{array}{c}0.361 \\
(0.250)\end{array}$ & $\begin{array}{c}0.385 \\
(0.217)\end{array}$ \\
\hline $\mathrm{N}$ & $1,474,985$ & $1,533,704$ & 227,494 & 225,952 & 349,429 & 319,001 \\
\hline R-squared & 0.857 & 0.861 & 0.871 & 0.868 & 0.826 & 0.829 \\
\hline \multicolumn{7}{|l|}{ Fixed effects } \\
\hline Bank*Firm & Y & Y & Y & Y & Y & $\mathrm{Y}$ \\
\hline Firm*Time & Y & Y & Y & Y & Y & $\mathrm{Y}$ \\
\hline Bank*'Time & $\mathrm{Y}$ & $\mathrm{Y}$ & $\mathrm{Y}$ & $\mathrm{Y}$ & $\mathrm{Y}$ & $\mathrm{Y}$ \\
\hline
\end{tabular}

Note: The dependent variable is the (log-)credit granted (drawn and undrawn) by bank "b" to firm "f" operating in sector "s" at time " $\mathrm{t}$ ". BQ (Borrower quality) indicates, for each borrower, the ratio between exposures in arrears and total exposures. Sup (Centralised supervision) is a dummy variable that takes value one for banks supervised at supranational level (i.e. directly by the ECB) after November 2014. EU non EA includes Romania and Check Republic that are in the European Union (EU) but not in the euro area (EA). Data are at semi-annual frequency covering the period 2012H1 - 2017H2 and, for each country, the sample includes the 3 smallest centrally supervised banks and the 3 largest non-centrally supervised banks. For EU non EA countries, centrally supervised banks are defined fictitiously based on the SSM significance criteria. Standard errors clustered at bank level in parentheses: ${ }^{*} \mathrm{p}<0.1,{ }^{* *} \mathrm{p}<0.05$, ${ }^{* * *} \mathrm{p}<0.01$. 
Table 7: Capacity and incentive hypotheses

\begin{tabular}{|c|c|c|c|c|c|c|c|c|}
\hline & \multicolumn{4}{|c|}{ Stressed Countries } & \multicolumn{4}{|c|}{ Non-Stressed Countries } \\
\hline & \multicolumn{2}{|c|}{$i=-1$} & \multicolumn{2}{|c|}{$\mathrm{i}=1$} & \multicolumn{2}{|c|}{$\mathrm{i}=-1$} & \multicolumn{2}{|c|}{$\mathrm{i}=1$} \\
\hline & $(1)$ & $(2)$ & (3) & (4) & (5) & $(6)$ & $(7)$ & (8) \\
\hline $\mathrm{BQ}_{\mathrm{f}, \mathrm{t}+\mathrm{i}}$ & $\begin{array}{c}-0.171 * * * \\
(0.0402)\end{array}$ & - & $\begin{array}{c}-0.173 * * * \\
(0.0479)\end{array}$ & - & $\begin{array}{c}-0.194 * * * \\
(0.0460)\end{array}$ & - & $\begin{array}{c}-0.184 * * * \\
(0.0360)\end{array}$ & - \\
\hline $\mathrm{BQ}_{\mathrm{f}, \mathrm{t}+\mathrm{i}} \times \operatorname{Sup}_{\mathrm{b}, \mathrm{t}-1}$ & $\begin{array}{c}-0.365^{* * *} \\
(0.0506)\end{array}$ & $\begin{array}{c}-0.218^{* *} \\
(0.0903)\end{array}$ & $\begin{array}{c}-0.400 * * * \\
(0.0516)\end{array}$ & $\begin{array}{c}-0.197 * * * \\
(0.0754)\end{array}$ & $\begin{array}{c}-0.282^{* * *} \\
(0.0987)\end{array}$ & $\begin{array}{c}-0.0276 \\
(0.135)\end{array}$ & $\begin{array}{c}-0.219 * * * \\
(0.0592)\end{array}$ & $\begin{array}{l}0.0724 \\
(0.101)\end{array}$ \\
\hline $\mathrm{NPL}_{\mathrm{b}, \mathrm{t}-1} \times \mathrm{BQ}_{\mathrm{f}, \mathrm{t}+\mathrm{i}}$ & $\begin{array}{c}1.932 * * * \\
(0.333)\end{array}$ & $\begin{array}{c}2.106 * * * \\
(0.496)\end{array}$ & $\begin{array}{c}1.299 * * * \\
(0.401)\end{array}$ & $\begin{array}{c}1.670 * * * \\
(0.427)\end{array}$ & $\begin{array}{c}1.441 * * * \\
(0.468)\end{array}$ & $\begin{array}{c}2.244 * * * \\
(0.859)\end{array}$ & $\begin{array}{c}1.460 * * * \\
(0.385)\end{array}$ & $\begin{array}{c}2.054 * * \\
(0.811)\end{array}$ \\
\hline $\mathrm{NPL}_{\mathrm{b}, \mathrm{t}-1} \times \mathrm{BQ}_{\mathrm{f}, \mathrm{t}+\mathrm{i}} \times \operatorname{Sup}_{\mathrm{b}, \mathrm{t}-1}$ & $\begin{array}{c}1.17 \\
(0.956)\end{array}$ & $\begin{array}{c}1.031 \\
(0.916)\end{array}$ & $\begin{array}{c}0.97 \\
(0.783)\end{array}$ & $\begin{array}{c}0.308 \\
(0.811)\end{array}$ & $\begin{array}{l}-0.492 \\
(0.772)\end{array}$ & $\begin{array}{c}0.471 \\
(1.552)\end{array}$ & $\begin{array}{c}0.856 \\
(0.546)\end{array}$ & $\begin{array}{c}1.287 \\
(1.106)\end{array}$ \\
\hline $\operatorname{Size}_{\mathrm{b}, \mathrm{s}, \mathrm{t}-1} \times \mathrm{BQ}_{\mathrm{f}, \mathrm{t}+\mathrm{i}}$ & $\begin{array}{l}0.000203 \\
(0.00354)\end{array}$ & $\begin{array}{l}-0.00448 \\
(0.00516)\end{array}$ & $\begin{array}{c}0.0006 \\
(0.00389)\end{array}$ & $\begin{array}{l}-0.00234 \\
(0.00394)\end{array}$ & $\begin{array}{c}0.00197 \\
(0.00300)\end{array}$ & $\begin{array}{c}0.00268 \\
(0.00623)\end{array}$ & $\begin{array}{l}-0.00148 \\
(0.00272)\end{array}$ & $\begin{array}{r}-0.000256 \\
(0.00508)\end{array}$ \\
\hline $\operatorname{Size}_{b, \mathrm{~s}, \mathrm{t}-1} \times \mathrm{BQ}_{\mathrm{f}, \mathrm{t}+\mathrm{i}} \times \operatorname{Sup}_{\mathrm{b}, \mathrm{t}-1}$ & $\begin{array}{c}0.00421 \\
(0.00470)\end{array}$ & $\begin{array}{c}-0.000585 \\
(0.00833)\end{array}$ & $\begin{array}{c}0.00478 \\
(0.00487)\end{array}$ & $\begin{array}{c}-0.000975 \\
(0.00745)\end{array}$ & $\begin{array}{c}0.00700 \\
(0.00459)\end{array}$ & $\begin{array}{l}-0.00531 \\
(0.00757)\end{array}$ & $\begin{array}{l}-0.00402 \\
(0.00320)\end{array}$ & $\begin{array}{c}-0.0122 * * \\
(0.00531)\end{array}$ \\
\hline $\operatorname{Large}_{\mathrm{b}} \times \mathrm{BQ}_{\mathrm{f}, \mathrm{t}+\mathrm{i}}$ & $\begin{array}{c}0.358 * * * \\
(0.0944)\end{array}$ & $\begin{array}{c}0.305^{*} \\
(0.178)\end{array}$ & $\begin{array}{c}0.503 * * * \\
(0.165)\end{array}$ & $\begin{array}{c}0.398^{* *} \\
(0.171)\end{array}$ & $\begin{array}{c}0.327^{* * *} \\
(0.0979)\end{array}$ & $\begin{array}{l}0.0132 \\
(0.346)\end{array}$ & $\begin{array}{c}0.648^{* * *} \\
(0.0385)\end{array}$ & $\begin{array}{l}-0.342 \\
(0.221)\end{array}$ \\
\hline $\operatorname{Large}_{b} \times B_{\mathrm{f}, t+\mathrm{i}} \times \operatorname{Sup}_{\mathrm{b}, \mathrm{t}-1}$ & $\begin{array}{c}-0.470 * * \\
(0.207)\end{array}$ & $\begin{array}{c}-0.319 * \\
(0.190)\end{array}$ & $\begin{array}{c}-0.404 * * \\
(0.182)\end{array}$ & $\begin{array}{c}-0.219 * \\
(0.126)\end{array}$ & $\begin{array}{c}-0.824 * * * \\
(0.160)\end{array}$ & $\begin{array}{c}-0.0537 \\
(0.469)\end{array}$ & $\begin{array}{c}-0.367^{* * *} \\
(0.0938)\end{array}$ & $\begin{array}{c}0.152 \\
(0.305)\end{array}$ \\
\hline $\mathrm{N}$ & $39,811,038$ & $29,856,793$ & $36,120,663$ & $27,285,698$ & $6,262,908$ & $2,915,490$ & $5,642,723$ & $2,641,856$ \\
\hline R-squared & 0.705 & 0.773 & 0.716 & 0.780 & 0.835 & 0.866 & 0.851 & 0.869 \\
\hline \multicolumn{9}{|l|}{ Fixed effects } \\
\hline Bank*Firm & Y & Y & Y & Y & Y & Y & $\mathrm{Y}$ & Y \\
\hline Firm*Time & $\mathrm{N}$ & $\mathrm{Y}$ & $\mathrm{N}$ & $\mathrm{Y}$ & $\mathrm{N}$ & $\mathrm{Y}$ & $\mathrm{N}$ & $\mathrm{Y}$ \\
\hline Sector*Time & $\mathrm{Y}$ & - & $\mathrm{Y}$ & - & $\mathrm{Y}$ & - & $\mathrm{Y}$ & - \\
\hline Bank*Time & $\mathrm{Y}$ & $\mathrm{Y}$ & $\mathrm{Y}$ & $\mathrm{Y}$ & $\mathrm{Y}$ & $\mathrm{Y}$ & $\mathrm{Y}$ & $\mathrm{Y}$ \\
\hline
\end{tabular}

Note: The dependent variable is the (log-)credit granted (drawn and undrawn) by bank "b" to firm "f" operating in sector "s" at time "t". BQ (borrower quality) indicates, for each borrower, the ratio between exposures in arrears and total exposures. Sup (centralised supervision) is a dummy variable that takes value one for banks supervised at supranational level (i.e. directly by the ECB) after November 2014. Size is the market share of the bank in each sector in each period. Large is a dummy variable that takes value 1 if the total assets of the bank are larger than Euro 500bn. The NPL ratio measures for each bank and time period the share of non-performing exposure to total exposure. Data are at semi-annual covering the period 2012H1 - $2017 \mathrm{H} 2$. "--" implies that the fixed effects are spanned by other effects, while "Y" and "N" imply that those fixed effects are included, and not included, respectively. Standard errors clustered at bank level in parentheses: ${ }^{*} \mathrm{p}<0.1,{ }^{* *}$ $\mathrm{p}<0.05, * * * \mathrm{p}<0.01$. 
Table 8: Capacity and incentive hypotheses: 20 different individual regressions for each alternative measure of large banks (stressed countries)

\begin{tabular}{|c|c|c|c|c|}
\hline \multirow[b]{2}{*}{$>200$ bn } & \multicolumn{2}{|c|}{ Full sample } & \multicolumn{2}{|c|}{ Restricted Sample } \\
\hline & $\begin{array}{c}-0.215^{* *} \\
(0.109)\end{array}$ & $\begin{array}{c}0.206 \\
(0.142)\end{array}$ & $\begin{array}{l}-0.174 \\
(0.111)\end{array}$ & $\begin{array}{c}0.112 \\
(0.159)\end{array}$ \\
\hline$>300$ bn & $\begin{array}{c}-0.425^{* * *} \\
(0.147)\end{array}$ & $\begin{array}{l}-0.198 \\
(0.178)\end{array}$ & $\begin{array}{c}-0.396 * * * \\
(0.147)\end{array}$ & $\begin{array}{c}-0.388^{*} \\
(0.196)\end{array}$ \\
\hline$>400$ bn & $\begin{array}{c}-0.438^{* *} \\
(0.190)\end{array}$ & $\begin{array}{c}-0.325^{*} \\
(0.176)\end{array}$ & $\begin{array}{c}-0.407 * * \\
(0.190)\end{array}$ & $\begin{array}{c}-0.513^{* * *} \\
(0.192)\end{array}$ \\
\hline$>500$ bn & $\begin{array}{c}-0.470 * * \\
(0.207)\end{array}$ & $\begin{array}{c}-0.319 * \\
(0.190)\end{array}$ & $\begin{array}{c}-0.443 * * \\
(0.206)\end{array}$ & $\begin{array}{c}-0.508^{* *} \\
(0.196)\end{array}$ \\
\hline Largest bank in country & $\begin{array}{c}0.00383 \\
(0.147)\end{array}$ & $\begin{array}{l}0.0388 \\
(0.107)\end{array}$ & $\begin{array}{c}0.000374 \\
(0.138)\end{array}$ & $\begin{array}{l}0.0158 \\
(0.153)\end{array}$ \\
\hline $\mathrm{N}$ & $39,811,038$ & $29,856,793$ & $26,535,557$ & $17,059,229$ \\
\hline Fixed effects & & & & \\
\hline Bank*Firm & $\mathrm{Y}$ & Y & Y & Y \\
\hline Firm*Time & $\mathrm{N}$ & Y & $\mathrm{N}$ & $\mathrm{Y}$ \\
\hline Sector*Time & $\mathrm{Y}$ & - & $\mathrm{Y}$ & - \\
\hline Bank*Time & $\mathrm{Y}$ & $\mathrm{Y}$ & $\mathrm{Y}$ & $\mathrm{Y}$ \\
\hline
\end{tabular}

Note: The specification used is identical to that in Table 7 but with different definitions of the variable Large. That is, the dependent variable is the (log-)credit granted (drawn and undrawn) by bank "b" to firm " $\mathrm{f}$ " operating in sector "s" at time "t", where the bank operates in stressed countries. The table reports the estimated coefficients (from 20 different regressions) of the triple interaction $B Q *$ Sup*Large for stressed countries under different definitions of the variable "Large". These definitions (indicated in the first column) include banks with total assets exceeding Euro 200bn, 300bn, 400bn, and 500bn, or the largest bank in each country (Largest bank in country). Results in first two columns are obtained using the entire sample whereas those in last two columns use a restricted sample including only the same number of centrally and locally supervised banks. "-" implies that the fixed effects are spanned by other effects, while "Y" and "N" imply that those fixed effects are included, and not included, respectively. Standard errors clustered at bank level in parentheses: ${ }^{*} \mathrm{p}<0.1,{ }^{* *} \mathrm{p}<0.05,{ }^{* * *}$ $\mathrm{p}<0.01$. 
Table 9: Bank supervision and monetary policy

\begin{tabular}{|c|c|c|c|c|}
\hline & \multicolumn{2}{|c|}{ Stressed Countries } & \multicolumn{2}{|c|}{ Non Stressed Countries } \\
\hline & $(1)$ & $(2)$ & $(3)$ & (4) \\
\hline$B Q_{f, t-1}$ & $\begin{array}{c}-0.422 * * * \\
(0.0626)\end{array}$ & & $\begin{array}{c}-0.254 * * * \\
(0.0534)\end{array}$ & \\
\hline $\mathrm{BQ}_{\mathrm{f}, \mathrm{t}-1} \times \operatorname{Sup}_{\mathrm{b}, \mathrm{t}-1}$ & $\begin{array}{c}-0.527^{* * *} \\
(0.125)\end{array}$ & $\begin{array}{c}-0.328 * \\
(0.198)\end{array}$ & $\begin{array}{c}-0.248^{*} \\
(0.133)\end{array}$ & $\begin{array}{l}-0.113 \\
(0.178)\end{array}$ \\
\hline $\mathrm{BQ}_{\mathrm{f}, \mathrm{t}-1} \times \operatorname{Shock}_{\mathrm{t}-1}^{\mathrm{MP}}$ & $\begin{array}{c}-0.0170 * * \\
(0.00713)\end{array}$ & & $\begin{array}{c}-0.0168^{* * *} \\
(0.00583)\end{array}$ & \\
\hline $\mathrm{BQ}_{\mathrm{f}, \mathrm{t}-1} \times \operatorname{Sup}_{\mathrm{b}, \mathrm{t}-1} \times \operatorname{Shock}_{\mathrm{t}-1}{ }^{\mathrm{MP}}$ & $\begin{array}{c}0.0403 * * * \\
(0.0154)\end{array}$ & $\begin{array}{c}0.0535^{* *} \\
(0.0233)\end{array}$ & $\begin{array}{c}0.0222^{* * *} \\
(0.00811)\end{array}$ & $\begin{array}{c}0.0278^{* *} \\
(0.0125)\end{array}$ \\
\hline $\begin{array}{l}\mathrm{N} \\
\mathrm{R} \text {-squared }\end{array}$ & $\begin{array}{l}39,811,038 \\
0.705\end{array}$ & $\begin{array}{l}29,856,793 \\
0.773\end{array}$ & $\begin{array}{l}6,262,908 \\
0.835\end{array}$ & $\begin{array}{l}2,915,490 \\
0.866\end{array}$ \\
\hline Fixed effects & & & & \\
\hline Bank*Firm & $\mathrm{Y}$ & Y & $\mathrm{Y}$ & Y \\
\hline Firm*Time & $\mathrm{N}$ & $\mathrm{Y}$ & $\mathrm{N}$ & $\mathrm{Y}$ \\
\hline Sector*Time & $\mathrm{Y}$ & - & $\mathrm{Y}$ & - \\
\hline Bank*Time & $\mathrm{Y}$ & $\mathrm{Y}$ & $\mathrm{Y}$ & $\mathrm{Y}$ \\
\hline
\end{tabular}

Note: The dependent variable is the (log-)credit granted (drawn and undrawn) by bank "b" to firm "f” operating in sector "s" at time "t". BQ (borrower quality) indicates, for each borrower, the ratio between exposures in arrears and total exposures. Sup (centralised supervision) is a dummy variable that takes value one for banks supervised at supranational level (i.e. directly by the ECB) after November 2014. Shock ${ }^{\mathrm{MP}}$ is the first principal component of the monetary policy surprises extracted from the high-frequency intraday yields at different maturities during all dates of policy announcements covered in the sample. Data are at semi-annual covering the period 2012H1 - 2017H2. “-” implies that the fixed effects are spanned by other effects, while "Y" and "N" imply that those fixed effects are included, and not included, respectively. Standard errors clustered at bank level in parentheses: ${ }^{*} \mathrm{p}<0.1, * * \mathrm{p}<0.05, * * * \mathrm{p}<0.01$. 
Table 10: Bank supervision, monetary policy, and large banks

\begin{tabular}{|c|c|c|c|c|c|c|c|c|}
\hline & \multicolumn{4}{|c|}{ Stressed countries } & \multicolumn{4}{|c|}{ Non-stressed countries } \\
\hline & (1) & $(2)$ & (3) & (4) & (5) & (6) & (7) & $(8)$ \\
\hline$B Q_{\mathrm{f}, \mathrm{t}-1}$ & $\begin{array}{l}-0.0280 \\
(0.0510)\end{array}$ & $\begin{array}{c}-0.0588^{*} \\
(0.0264)\end{array}$ & $\begin{array}{c}-0.0599 * \\
(0.0324)\end{array}$ & & $\begin{array}{l}-0.0881 \\
(0.0597)\end{array}$ & $\begin{array}{c}-0.146^{* * *} \\
(0.0457)\end{array}$ & $\begin{array}{c}-0.152^{* * *} \\
(0.0453)\end{array}$ & \\
\hline $\mathrm{BQ}_{\mathrm{f}, \mathrm{t}-1} \times \operatorname{Sup}_{\mathrm{b}, \mathrm{t}-1}$ & $\begin{array}{c}-0.428^{* * *} \\
(0.0622)\end{array}$ & $\begin{array}{c}-0.367 * * * \\
(0.0553)\end{array}$ & $\begin{array}{c}-0.362^{* * *} \\
(0.0552)\end{array}$ & $\begin{array}{c}-0.207^{*} \\
(0.112)\end{array}$ & $\begin{array}{c}-0.401 * * * \\
(0.117)\end{array}$ & $\begin{array}{c}-0.319 * * * \\
(0.0977)\end{array}$ & $\begin{array}{c}-0.312^{* * *} \\
(0.0975)\end{array}$ & $\begin{array}{l}-0.086^{*} \\
(0.045)\end{array}$ \\
\hline $\mathrm{BQ}_{\mathrm{f}, \mathrm{t}-1} \times$ Shock $_{\mathrm{t}-1}{ }^{\mathrm{MP}}$ & $\begin{array}{c}-0.0209^{* *} \\
(0.00486)\end{array}$ & $\begin{array}{c}-0.0143 * * * \\
(0.00463)\end{array}$ & $\begin{array}{c}-0.0112^{* * *} \\
(0.00432)\end{array}$ & & $\begin{array}{c}-0.0219 * * * \\
(0.00508)\end{array}$ & $\begin{array}{c}-0.0275^{* * *} \\
(0.00719)\end{array}$ & $\begin{array}{c}-0.0249 * * * \\
(0.00712)\end{array}$ & \\
\hline $\mathrm{BQ}_{\mathrm{f}, \mathrm{t}-1} \times \operatorname{Sup}_{\mathrm{b}, \mathrm{t}-1} \times \operatorname{Shock}_{\mathrm{t}-1}{ }^{\mathrm{MP}}$ & & $\begin{array}{c}0.0175 \\
(0.0101)\end{array}$ & $\begin{array}{c}0.0370^{* *} \\
(0.0159)\end{array}$ & $\begin{array}{c}0.0475^{* *} \\
(0.0241)\end{array}$ & & $\begin{array}{c}0.0165^{* *} \\
(0.0083)\end{array}$ & $\begin{array}{c}0.0117^{*} \\
(0.00518)\end{array}$ & $\begin{array}{c}0.0372 * \\
(0.0197)\end{array}$ \\
\hline $\operatorname{Large}_{\mathrm{b}} \times \mathrm{BQ}_{\mathrm{f}, \mathrm{t}-1}$ & $\begin{array}{c}0.268^{* *} \\
(0.131)\end{array}$ & $\begin{array}{c}0.328^{* *} \\
(0.149)\end{array}$ & $\begin{array}{c}0.361 \text { ** } \\
(0.141)\end{array}$ & $\begin{array}{c}0.211 \\
(0.190)\end{array}$ & $\begin{array}{c}0.291^{* * *} \\
(0.0791)\end{array}$ & $\begin{array}{c}0.314 * * * \\
(0.0933)\end{array}$ & $\begin{array}{c}0.328^{* * *} \\
(0.0881)\end{array}$ & $\begin{array}{c}0.145 \\
(0.316)\end{array}$ \\
\hline $\operatorname{Large}_{b} \times B Q_{f, t-1} \times \operatorname{Sup}_{b, t-1}$ & & $\begin{array}{c}-0.580^{* * *} \\
(0.208)\end{array}$ & $\begin{array}{c}-0.627^{* * *} \\
(0.202)\end{array}$ & $\begin{array}{c}-0.434^{* *} \\
(0.205)\end{array}$ & & $\begin{array}{c}-0.813^{* * *} \\
(0.163)\end{array}$ & $\begin{array}{c}-0.831 * * * \\
(0.158)\end{array}$ & $\begin{array}{c}-0.4798^{*} \\
(0.255)\end{array}$ \\
\hline $\operatorname{Large}_{\mathrm{b}} \times \mathrm{BQ}_{\mathrm{f}, \mathrm{t}-1} \times$ Shock $_{\mathrm{t}-1}{ }^{\mathrm{MP}}$ & & $\begin{array}{c}-0.0136 \\
(0.00929)\end{array}$ & $\begin{array}{c}-0.0465^{* * *} \\
(0.00841)\end{array}$ & $\begin{array}{c}-0.0223^{*} \\
(0.0119)\end{array}$ & & $\begin{array}{l}-0.0122 \\
(0.0148)\end{array}$ & $\begin{array}{c}-0.033^{*} \\
(0.0178)\end{array}$ & $\begin{array}{c}-0.141 * * * \\
(0.0460)\end{array}$ \\
\hline $\operatorname{Large}_{\mathrm{b}} \times \mathrm{BQ}_{\mathrm{f}, \mathrm{t}-1} \times$ Shock $_{\mathrm{t}-1}^{\mathrm{MP}} \times \operatorname{Sup}_{\mathrm{b}, \mathrm{t}-1}$ & & & $\begin{array}{c}0.0513^{* * *} \\
(0.00886)\end{array}$ & $\begin{array}{c}0.0452^{* * *} \\
(0.0146)\end{array}$ & & & $\begin{array}{c}0.0208^{*} \\
(0.0108)\end{array}$ & $\begin{array}{c}0.164 * * * \\
(0.046)\end{array}$ \\
\hline $\begin{array}{l}\mathrm{N} \\
\mathrm{R} \text {-squared }\end{array}$ & $\begin{array}{l}39,811,038 \\
0.705\end{array}$ & $\begin{array}{c}39,811,038 \\
0.705\end{array}$ & $\begin{array}{c}39,811,038 \\
0.705\end{array}$ & $\begin{array}{c}29,856,793 \\
0.773\end{array}$ & $\begin{array}{l}6,262,908 \\
0.835\end{array}$ & $\begin{array}{l}6,262,908 \\
0.835\end{array}$ & $\begin{array}{l}6,262,908 \\
0.835\end{array}$ & $\begin{array}{c}2,915,490 \\
0.866\end{array}$ \\
\hline Fixed effects & & & & & & & & \\
\hline Bank*Firm & $\mathrm{Y}$ & $\mathrm{Y}$ & $\mathrm{Y}$ & $\mathrm{Y}$ & $\mathrm{Y}$ & Y & $\mathrm{Y}$ & $\mathrm{Y}$ \\
\hline Firm*Time & $\mathrm{N}$ & $\mathrm{N}$ & $\mathrm{N}$ & $\mathrm{Y}$ & $\mathrm{N}$ & $\mathrm{N}$ & $\mathrm{N}$ & $\mathrm{Y}$ \\
\hline Sector*Time & Y & Y & Y & - & Y & Y & $\mathrm{Y}$ & - \\
\hline Bank*Time & $\mathrm{Y}$ & $\mathrm{Y}$ & $\mathrm{Y}$ & $\mathrm{Y}$ & $\mathrm{Y}$ & $\mathrm{Y}$ & $\mathrm{Y}$ & $\mathrm{Y}$ \\
\hline
\end{tabular}

Note: The dependent variable is the (log-)credit granted (drawn and undrawn) by bank "b" to firm "f" operating in sector "s" at time "t". BQ (borrower quality) indicates, for each borrower, the ratio between exposures in arrears and total exposures. Sup (centralised supervision) is a dummy variable that takes value one for banks supervised at supranational level (i.e. directly by the ECB) after November 2014. Shock ${ }^{\mathrm{MP}}$ is the first principal component of the monetary policy surprises extracted from the high-frequency intraday yields at different maturities during all dates of policy announcements covered in the sample. Large is a dummy variable that takes value 1 if the total assets of the bank are larger than Euro 500bn. Data are at semi-annual for the period 2012H1 - 2017H2. "-" implies that the fixed effects are spanned by other effects, while "Y" and "N" imply that those fixed effects are included, and not included, respectively. Standard errors clustered at bank level in parentheses: ${ }^{*} \mathrm{p}<0.1,{ }^{* *} \mathrm{p}<0.05$, *** $\mathrm{p}<0.01$. 


\section{Figure 1: Share of firms with multiple lending relationships}

As \% of total borrowers

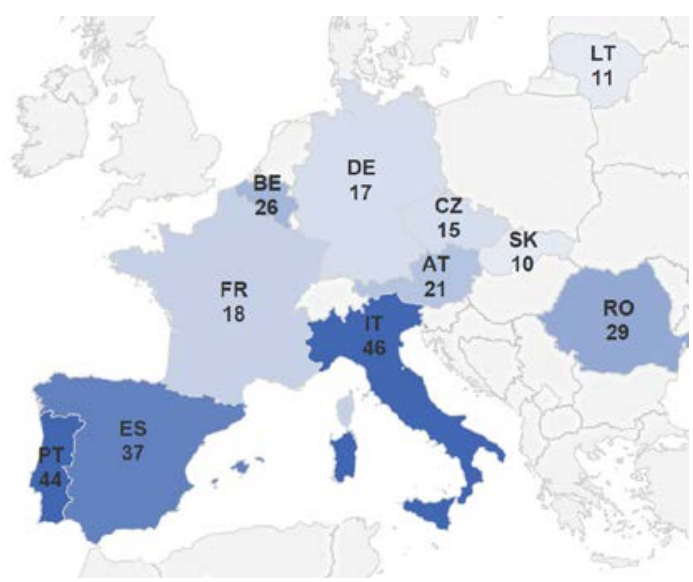

As \% of total credit

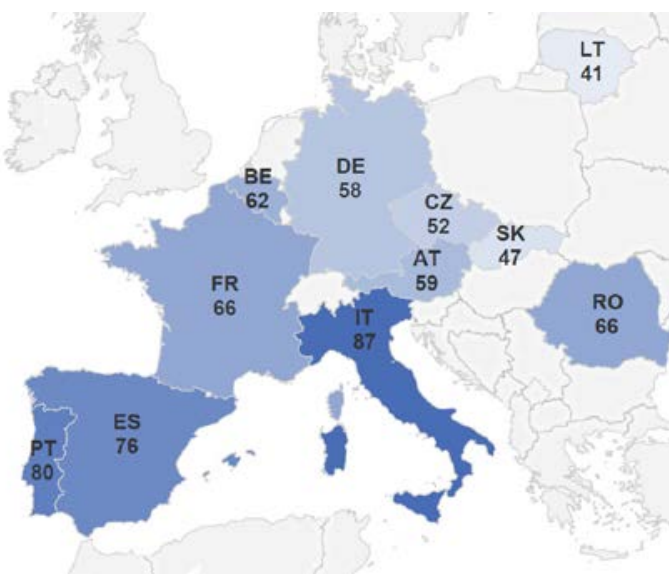

Notes: The chart reports for each country included in the dataset the share of non-financial corporations with multiple lending relationships as a share of the total number of borrowers (left panel) and of total lending (right panel).

\section{Figure 2: Robustness on the timing of banking supervision}

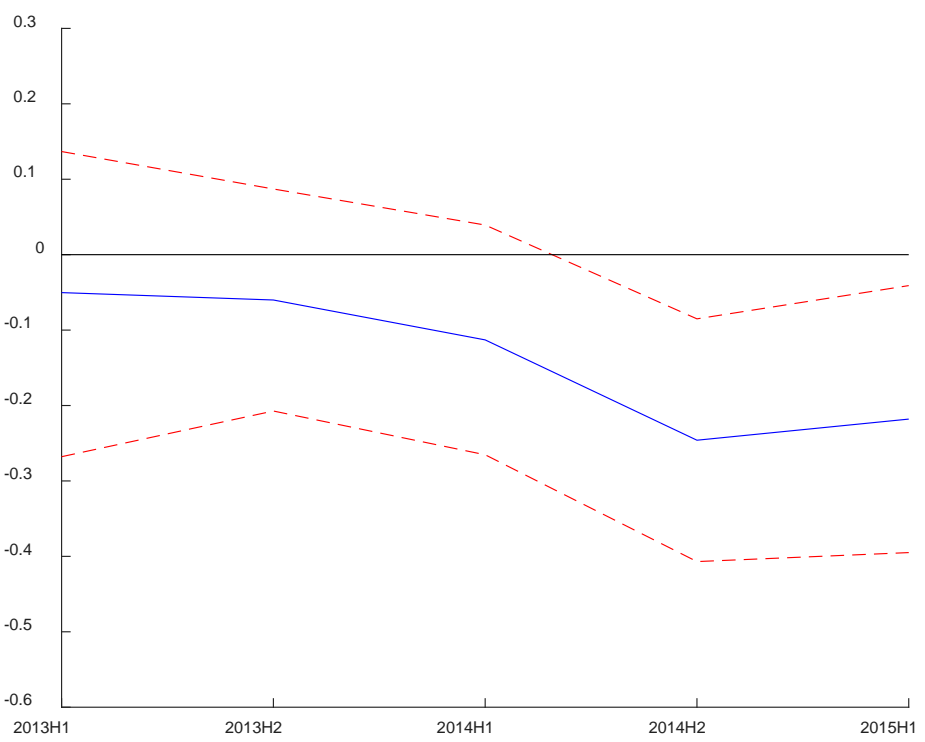

Notes: Estimated coefficient of the interaction $\mathrm{BQ}^{*}$ Sup from equation (1), based on different dates for the effective start of bank supervision. The specifications control for Bank*time, Bank*firm, and Firm*time fixed effects (Country*time and sector*time fixed effects are spanned by the previous effects). 
Figure 3: Monetary policy surprises

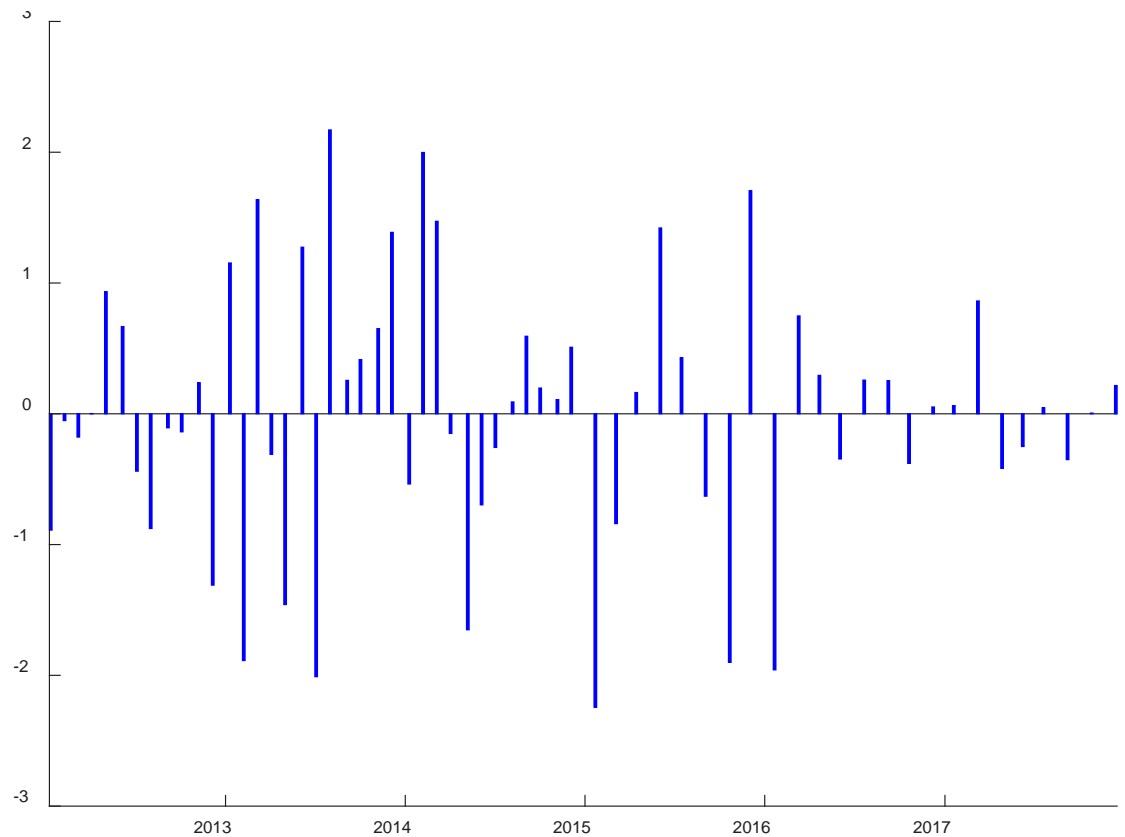

Note: the figure shows the first principal component of the monetary policy surprises extracted from the high-frequency intraday yields at different maturities during dates of policy announcements as included in the Euro Area Monetary Policy Event-Study Database. Positive (negative) values indicate policy tightening (easing). 


\section{Appendix}

Table A.1 Supervision and bank credit supply

\begin{tabular}{|c|c|c|c|c|}
\hline & \multicolumn{2}{|c|}{ Stressed Countries } & \multicolumn{2}{|c|}{ Non Stressed Countries } \\
\hline & $(1)$ & $(2)$ & (3) & (4) \\
\hline $\operatorname{Sup}_{b, t-1}$ & $\begin{array}{c}0.110^{*} \\
(0.0616)\end{array}$ & $\begin{array}{c}0.110^{*} \\
(0.0642)\end{array}$ & $\begin{array}{c}0.0578 \\
(0.0652)\end{array}$ & $\begin{array}{c}0.155^{* *} \\
(0.0698)\end{array}$ \\
\hline$B Q_{f, t-1}$ & $\begin{array}{l}-0.0450 \\
(0.0456)\end{array}$ & - & $\begin{array}{c}-0.0997 * * \\
(0.0439)\end{array}$ & - \\
\hline $\mathrm{BQ}_{\mathrm{f}, \mathrm{t}-1} \times \operatorname{Sup}_{\mathrm{b}, \mathrm{t}-1}$ & $\begin{array}{c}-0.447 * * * \\
(0.0673)\end{array}$ & $\begin{array}{c}-0.358^{* * *} \\
(0.104)\end{array}$ & $\begin{array}{c}-0.446^{* * *} \\
(0.112)\end{array}$ & $\begin{array}{c}-0.272^{* * *} \\
(0.0963)\end{array}$ \\
\hline $\mathrm{N}$ & $39,820,155$ & $29,866,102$ & $6,263,603$ & $2,916,268$ \\
\hline R-squared & 0.682 & 0.751 & 0.830 & 0.859 \\
\hline \multicolumn{5}{|l|}{ Fixed effects } \\
\hline Bank*Firm & $\mathrm{Y}$ & $\mathrm{Y}$ & $\mathrm{Y}$ & $\mathrm{Y}$ \\
\hline Firm*Time & $\mathrm{N}$ & $\mathrm{Y}$ & $\mathrm{N}$ & $\mathrm{Y}$ \\
\hline Sector*Time & $\mathrm{Y}$ & - & $\mathrm{Y}$ & - \\
\hline Bank & $\mathrm{Y}$ & $\mathrm{Y}$ & $\mathrm{Y}$ & $\mathrm{Y}$ \\
\hline
\end{tabular}

Note: The dependent variable is the (log-)credit granted (drawn and undrawn) by bank "b” to firm "f” operating in sector "s" at time "t". BQ (Borrower quality) indicates, for each borrower, the ratio between exposures in arrears and total exposures. Sup (Centralised supervision) is a dummy variable that takes value one for banks supervised at supranational level (i.e. directly by the ECB) after November 2014. Data are at semi-annual for the period 2012H1 - 2017H2. "-" implies that the fixed effects are spanned by other effects, while "Y" and "N" imply that those fixed effects are included, and not included, respectively. Standard errors clustered at bank and firm level in parentheses: $* \mathrm{p}<0.1, * * \mathrm{p}<0.05$, *** $\mathrm{p}<0.01$. 


\section{Table A.2 Capacity and incentive hypotheses: 20 individual regressions for each alternative measure of large banks (non-stressed countries)}

\begin{tabular}{|c|c|c|c|c|}
\hline & \multicolumn{2}{|c|}{ Full sample } & \multicolumn{2}{|c|}{ Restricted Sample } \\
\hline$>200 \mathrm{bn}$ & $\begin{array}{c}-0.740^{* * *} \\
(0.157)\end{array}$ & $\begin{array}{l}-0.162 \\
(0.246)\end{array}$ & $\begin{array}{c}-0.707 * * * \\
(0.154)\end{array}$ & $\begin{array}{l}-0.187 \\
(0.243)\end{array}$ \\
\hline$>300$ bn & $\begin{array}{c}-0.785^{* * *} \\
(0.166)\end{array}$ & $\begin{array}{c}0.287 \\
(0.493)\end{array}$ & $\begin{array}{c}-0.749 * * * \\
(0.164)\end{array}$ & $\begin{array}{c}0.277 \\
(0.481)\end{array}$ \\
\hline$>400$ bn & $\begin{array}{c}-0.785^{* * *} \\
(0.166)\end{array}$ & $\begin{array}{c}0.287 \\
(0.493)\end{array}$ & $\begin{array}{c}-0.749 * * * \\
(0.164)\end{array}$ & $\begin{array}{c}0.277 \\
(0.481)\end{array}$ \\
\hline$>500$ bn & $\begin{array}{c}-0.824 * * * \\
(0.160)\end{array}$ & $\begin{array}{l}-0.0537 \\
(0.469)\end{array}$ & $\begin{array}{c}-0.790 * * * \\
(0.156)\end{array}$ & $\begin{array}{l}-0.0724 \\
(0.445)\end{array}$ \\
\hline Largest bank in country & $\begin{array}{l}-0.188 \\
(0.194)\end{array}$ & $\begin{array}{c}0.529 \\
(0.362)\end{array}$ & $\begin{array}{l}-0.184 \\
(0.188)\end{array}$ & $\begin{array}{c}0.562 \\
(0.368)\end{array}$ \\
\hline $\mathrm{N}$ & $6,262,908$ & $2,915,490$ & $5,663,549$ & $2,342,131$ \\
\hline$\overline{\text { Fixed effects }}$ & & & & \\
\hline Bank*Firm & $\mathrm{Y}$ & Y & Y & $\mathrm{Y}$ \\
\hline Firm*Time & $\mathrm{N}$ & Y & $\mathrm{N}$ & Y \\
\hline Sector*Time & $\mathrm{Y}$ & - & Y & - \\
\hline Bank*Time & $\mathrm{Y}$ & $\mathrm{Y}$ & $\mathrm{Y}$ & $\mathrm{Y}$ \\
\hline
\end{tabular}

Note: This table is identical as Table 7, but with different definitions of the variable Large, and identical to Table 8, but for non-stressed countries instead. That is, the dependent variable is the (log-)credit granted (drawn and undrawn) by bank "b" to firm "f”" operating in sector "s" at time "t", where the bank operates in non-stressed countries. The table reports the estimated coefficients (from 20 different regressions) of the triple interaction $B Q^{*}$ Sup*Large for stressed countries under different definitions of the variable "Large". These definitions (indicated in the first column) include banks with total assets exceeding Euro 200bn, 300bn, 400bn, and 500bn, or the largest bank in each country (Largest bank in country). Results in first two columns are obtained using the entire sample whereas those in last two columns use a restricted sample including only the same number of centrally and locally supervised banks. "-” implies that the fixed effects are spanned by other effects, while "Y" and "N" imply that those fixed effects are included, and not included, respectively. Standard errors clustered at bank level in parentheses: ${ }^{*} \mathrm{p}<0.1,{ }^{* *} \mathrm{p}<0.05$, *** $\mathrm{p}<0.01$. 